\title{
Concentrations of mineral aerosol from desert to plains across the central Rocky Mountains, western United States
}

Richard L. Reynolds ${ }^{\mathrm{a}, \mathrm{b}, *}$, Seth M. Munson ${ }^{\mathrm{c}}$, Daniel Fernandez ${ }^{\mathrm{d}}$, Harland L. Goldstein ${ }^{\mathrm{a}}$, Jason C. Neff ${ }^{\mathrm{e}}$

${ }^{a}$ U.S. Geological Survey, Geosciences and Environmental Change Science Center, Box 25046, Denver, CO 80225 USA

${ }^{\mathrm{b}}$ Department of Earth Sciences, University of Minnesota, Minneapolis, MN 55455 USA

${ }^{c}$ U.S. Geological Survey, Southwest Biological Science Center, 2255 N. Gemini Dr., Flagstaff, AZ 86001 USA

${ }^{\mathrm{d}}$ Department of Geological Sciences, University of Colorado at Boulder, UCB 399, Boulder, CO, 80309 USA

${ }^{\mathrm{e}}$ Environmental Studies Program, University of Colorado at Boulder, UCB 397, Boulder, CO, 80309 USA

*Corresponding Author Email: rreynolds@usgs.gov 


\begin{abstract}
Mineral dusts can have profound effects on climate, clouds, ecosystem processes, and human health. Because regional dust emission and deposition in western North America is not well understood, measurements of total suspended particulate (TSP) from 2011 to 2013 were made along a 500-km transect of five remote sites in Utah and Colorado, USA. The TSP concentrations in $\mu \mathrm{g} \mathrm{m}^{-3}$ adjusted to a 24-hour period were relatively high at the two westernmost, dryland sites at Canyonlands National Park (mean=135) and at Mesa Verde National Park (mean=99), as well as at the easternmost site on the Great Plains (mean=143). The TSP concentrations at the two intervening montane sites were less, with more loading on the western slope of the Rocky Mountains (Telluride, mean=68) closest to the desert sites compared with the site on the eastern slope (Niwot Ridge, mean=58). Dust concentrations were commonly highest during late winter-late spring, when Pacific frontal storms are the dominant causes of regional wind. Low concentrations $(<7 \mathrm{wt} . \%)$ of organic matter indicated that rock-derived mineral particles composed most TSP. Most TSP mass was carried by particle sizes larger than $10 \mu \mathrm{m}(\mathrm{PM}>10)$, as revealed by relatively low average daily concentrations of fine $\left(<5 \mu \mathrm{g} \mathrm{m}^{-3} ; \mathrm{PM}_{2.5}\right)$ and coarse $(<10 \mu \mathrm{g}$ $\left.\mathrm{m}^{-3} ; \mathrm{PM}_{2.5-10}\right)$ fractions monitored at or near four sites. Standard air-quality measurements for $\mathrm{PM}_{2.5}$ and $\mathrm{PM}_{10}$ apparently do not capture the large majority of mineral-particulate pollution in the remote western interior U.S.
\end{abstract}

Keywords: desert dust; air pollution; mineral aerosols; total suspended particulates (TSP); western North America

\title{
1. Introduction
}

Deserts produce massive quantities of mineral aerosols with implications for air quality, human health, biogeochemistry, and climate. At a global scale, the large deserts of Asia and Africa dominate 
dust production and generate aerosols that are frequently transported over thousands of kilometers. Over these long transport distances, dusts are generally in the $\mathrm{PM}_{10}$ (particulate matter less than $10 \mu \mathrm{m}$ in aerodynamic diameter) size class (Pye, 1987; VanCuren and Cahill, 2002; Goudie and Middleton, 2006; Mahowald et al., 2015; cf., Menéndez et al., 2014; van der Does et al., 2015). Particles in this size class can remain suspended in the atmosphere for many days. At a more local scale, strong winds can create large dust clouds that can temporarily diminish visibility and air quality. When these local events occur, they are intense but are often restricted to small areas close to $(<100 \mathrm{~km})$ large dust sources. In this study, we focus on dust transport at an intermediate, regional spatial scale of about $100 \mathrm{~km}$ to about $1000 \mathrm{~km}$ that lies between local and the global scales. This spatial scale is critical to understand because many population centers lie on the margins of deserts and because large amounts of dust can be transported over these intermediate distances with effects on air quality, human health, and biogeochemistry that are unique to this regional scale. Moreover, such regional dust-transport events are rarely documented, and their dusts include particle-size classes that are not commonly captured by the air quality/particulate monitoring techniques used in most economically developed nations (but see Knight et al., 1995; Chan et al., 2005, McTainsh et al., 2005; Shao et al., 2007; Leys et al., 2011, as examples of regional dust studies in Australia).

Atmospheric particulate monitoring generally focuses on small particles less than $2.5 \mu \mathrm{m}$ in diameter $\left(\mathrm{PM}_{2.5}\right)$ and on the slightly larger $\mathrm{PM}_{10}$. We previously showed that the $\mathrm{PM}_{2.5}$ and $\mathrm{PM}_{10}$ particle-size classes composed only a small amount of the total suspended particulate (TSP) concentrations in desert settings on the Colorado Plateau (southeastern Utah and southwestern Colorado) (Neff et al., 2013). This finding is not surprising in deserts where local wind erosion mobilizes large amounts of particles in the range of medium to coarse silt, approximately 20-60 $\mu \mathrm{m}$ (Pye, 1987). This result suggests the possibility of broad regional transport of dust particles that are too large to be 
detected by protocols of $\mathrm{PM}_{2.5}$ or $\mathrm{PM}_{10}$ sampling but small enough to be carried for hundreds of kilometers. To further suggest such a possibility, studies of dust deposition to snow cover in the San Juan Mountains, several hundred kilometers downwind from desert dust sources, including those on the Colorado Plateau, indicated that western U.S. desert dusts with a median size of $\sim 40 \mu \mathrm{m}$ in diameter can be mobilized and transported high into the Rocky Mountains (Lawrence et al., 2010). These observations are further complemented by an expanding body of literature showing that desert-derived particulate matter is routinely deposited to high-elevation soil and lake sediments (Neff et al., 2008; Reynolds et al., 2010; Lawrence et al., 2010, 2013; Ballantyne et al., 2011; Brahney et al., 2014; Routson et al., 2016) at sites in Colorado and Wyoming, USA. Such dust deposition is relevant because of its role in the biogeochemical cycles of high-elevation ecosystems (e.g., Lawrence et al., 2013; Brahney et al., 2014) and because dust on snow cover adversely affects water resources by accelerating melting of snow in downwind mountain ranges (Painter et al., 2010, 2012; Skiles et al., 2012, 2015).

The evidence for transport and deposition of desert dust into mountain regions of the western interior U.S. raises a number of questions about regional dust. These questions include the key issue of how far might large (defined here as greater than $10 \mu \mathrm{m}$ in diameter) dust particles dominate regional mineral aerosol transport? For example, are large particles routinely transported from the deserts of the western U.S. into and across the Rocky Mountains, and can such particles reach the heavily urbanized areas on the eastern edge of these mountains such as the Colorado Front Range? If such particles are an important part of regional mineral aerosol concentrations, then what implications do they have for air quality, human health, cloud formation and precipitation, as well as ecological/biogeochemical processes and effects?

Our primary purpose herein is to report on concentrations of TSP at five sites from the Colorado Plateau desert to the Great Plains in northeastern Colorado across the central Rocky Mountains, (Fig. 1) 
and to assess some causes, primarily seasonality of winds, for observed variability in these concentrations. This study, focusing on TSP deposition mainly during 2011 to early 2013, expands temporally and spatially a study by Neff et al. (2013) who measured TSP deposition during 2008-2011 at two dryland sites on the Colorado Plateau. At four of the sites in the current investigation, the TSP concentrations were compared to concentrations of $\mathrm{PM}_{10}$ and $\mathrm{PM}_{2.5}$ along with the derived difference between these measures, $\mathrm{PM}_{2.5-10}($ coarse $\mathrm{PM})$ and particles larger than $\mathrm{PM}_{10}\left(\right.$ denoted as $\left.\mathrm{PM}_{>10}\right)$. By comparing concentrations of TSP, $\mathrm{PM}_{2.5-10}$, and $\mathrm{PM}_{2.5}$, we evaluate the efficacy of $\mathrm{PM}_{10}$ and $\mathrm{PM}_{2.5}$ monitoring for particulate air pollution in part of the western interior United States. We complemented concentration measurements with particle-size distributions in samples from dust-on-snow collections in 2013 across much of the Rocky Mountain portion of the study area. These collections represent regional dust that is transported mainly between the Colorado Plateau and Great Plains during the late winterspring period of high dust activity. These results help document how particle sizes change with roughly estimated distances from source regions.

\section{Materials and Methods}

\subsection{Study sites}

The TSP sites span $505 \mathrm{~km}$ from the Colorado Plateau in Utah on the west to the Great Plains in Colorado on the east (Fig. 1; Table 1). The Canyonlands (CNP; $38.459^{\circ} \mathrm{N},-109.821^{\circ} \mathrm{W}, 1,798 \mathrm{~m}$ elevation) and Mesa Verde (MVNP; $\left.37.198^{\circ} \mathrm{N},-108.491^{\circ} \mathrm{W}, 2,170 \mathrm{~m}\right)$ sites are surrounded by semi-arid grassland and shrubland on the Colorado Plateau. Each of these sites is located within $10 \mathrm{~m}$ of an IMPROVE (Interagency Monitoring of Protected Visual Environments;

http://vista.cira.colostate.edu/improve/ accessed 10 June 2016) sampler that collects $\mathrm{PM}_{10}$ and $\mathrm{PM}_{2.5}$. 
The two mesic montane sites were in open meadows within mixed coniferous forest in the San Juan Mountains, one near Telluride (TEL; $37.956^{\circ} \mathrm{N},-107.827^{\circ} \mathrm{W}, 2,884 \mathrm{~m}$ ) and the other on Niwot Ridge (NIW; 40.039 ${ }^{\circ}$, $-105.5547^{\circ} \mathrm{W}, 3,123 \mathrm{~m}$; Niwot Ridge Long-Term Ecological Research site). Distances to the nearest $\mathrm{PM}_{10}$ monitoring sites were $4 \mathrm{~km}$ for TEL and $40 \mathrm{~km}$ for NIW in Rocky Mountain National Park. The Shortgrass Steppe site (SGS; $\left.40.806^{\circ} \mathrm{N},-104.755^{\circ} \mathrm{W}, 1,644 \mathrm{~m}\right)$ lies on the western limits of the Great Plains. This semi-arid site is surrounded by native grassland and dryland cropping at the Central Plains Experimental Range on the Pawnee National Grassland, and it lacked a nearby $\mathrm{PM}_{10}$ or $\mathrm{PM}_{2.5}$ sampler. In their southwest to northeast configuration, the TSP sites roughly represented increasing distance from drylands that produce dust as discussed in following sections.

We used particle-size analysis from dust-on-snow (DOS) layers deposited during water year 2013 (October 1-September 30) across much of the central Rocky Mountains as a surrogate for measurements of particle-size in the TSP filters. The DOS sites are generally aligned southwest to northeast as are the TSP sites (Fig. 1). Collections were made during late spring prior to complete snow melt, when all or most dust layers had merged as a result of melting snow cover. Thus, the DOS layers represented TSP deposition over a period of several months of winter to late spring. This approach has operational advantages over the limitations in separating particles from borosilicate filters used on the TSP samplers and subsequent microscopic examination, and it also enables comparison with our earlier results from filters at the CNP site (Neff et al., 2013). 


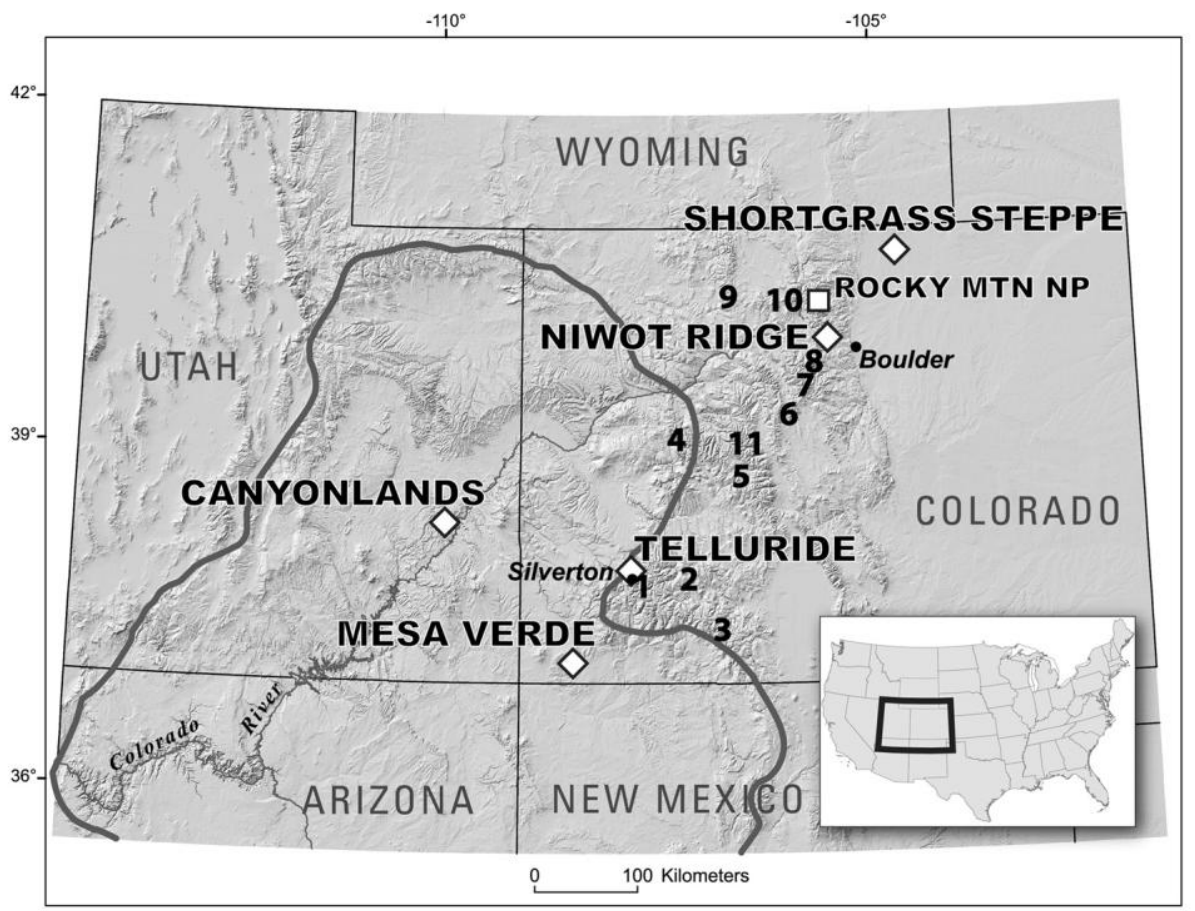

Figure 1. Map showing locations of TSP sampling sites (open diamonds) and dust-on-snow (DOS) sampling sites (numbers) across Utah and Colorado, USA, and outline of the Colorado Plateau (solid gray line line). Open square denotes location of $\mathrm{PM}_{10}$ and $\mathrm{PM}_{2.5}$ monitoring in Rocky Mountain National Park. Locations of $\mathrm{PM}_{10}$ and $\mathrm{PM}_{2.5}$ monitoring for all other sites, except Shortgrass Steppe, were $\leq 4 \mathrm{~km}$ from the associated TSP site. Locations of DOS sites are centered on the following: 1, Snow Angel (SASP) near Silverton; 2, Spring Creek Pass; 3, Wolf Creel Pass; 4, McClure Pass; 5, Park Cone; 6, Hoosier Pass; 7, Grizzly Peak; 8, Berthoud summit; 9, Rabbit Ears Pass; 10, Willow Creek Pass; 11, Independence Pass; http://snowstudies.org/CODOS; accessed 18 April 2016).

Table 1. Locations of sites with TSP samplers. Height $=$ height of sampler above ground level. $*$ Colocated or nearby $\mathrm{PM}_{10}$ and $\mathrm{PM}_{2.5}$ sampler.

$\begin{array}{cccccc}\text { Site } & \text { Setting } & \text { Lat } & \text { Long } & \text { Elev (m) } & \text { Height (m) } \\ \text { Canyonlands }(\mathrm{CNP})^{*} & \text { Desert Shrubland } & 38.4589 & -109.821 & 1798 & 4\end{array}$




$\begin{array}{cccccc}\text { Mesa Verde (MVNP)* } & \text { Desert Shrubland } & 37.1984 & -108.4907 & 2170 & 1.5 \\ \text { Telluride (TEL)* } & \text { Mixed Conifer } & 37.9557 & -107.827 & 2884 & 4 \\ \text { Niwot Ridge (NIW)* } & \text { Mixed Conifer } & 40.039 & -105.5547 & 3123 & 3 \\ \text { Shortgrass Steppe (SGS) } & \text { Grassland } & 40.8059 & -104.7551 & 1644 & 1.5\end{array}$

\subsection{Data collection}

At CNP, the TSP sampler was a Thermo Finnigan GS2310 High Volume Air Sampler with dual-stage motor, a Thermo G313 Mass Flow Controller, and a mechanical timer (Thermo Electron Corporation, Franklin, MA, USA) calibrated for a continuous air flow of 1,132 $1 \mathrm{~min}^{-1}$. At the MVNP, TEL, NIW, and SGS sites, we used a Staplex TSP-CF sampler, with a dual-stage motor and digital mass air-flow controller-recorder and timer (Staplex, Brooklyn, NY, USA) also calibrated for continuous air flow at 1,132 $1 \mathrm{~min}^{-1}$. These samplers, as well as the IMPROVE samplers with which we compare TSP data, follow well-established sampling protocols with periodic calibration. Continuous monitoring of air flow through the TSP samplers confirmed very little variation in flow. At each site, TSP was collected on a Whatman EPM 200020.3 by 25.4-cm filter. Filters remained on TSP samplers for approximately two weeks and were exposed to continuous sampling, with a few exceptions for down-time, mostly at the TEL site, noted in the results section and Supplementary material Table 1. We attempted to sample the same time period at each site, but this objective was difficult to achieve exactly because of collector schedules and remoteness of sites, coupled with weather conditions. Collection periods are listed in Supplementary material Table 1.

The filters were first weighed under controlled temperature and humidity conditions and then were pretreated for three days in a Millipure deionized water leach. After drying, filters were placed in a $500^{\circ} \mathrm{C}$ muffle furnace for six hours. After combustion, filters were put in plastic bags pre-soaked and triple rinsed with deionized water. At the end of each sampling period, filters were removed with nitrile 
gloves, folded in half to prevent sample loss, and placed in a plastic bag that stored the filter prior to sampling. All samples were analyzed for flow restrictions (due to accumulation of dust on the filter), and no such cases were observed.

The TSP mass on a filter was determined by calculating filter mass (in $\mathrm{mg}$ ) per $\mathrm{cm}^{2}$ using preand post-sampling filter weights determined on a micro-balance with readability of $2 \mu \mathrm{g}$ and standard deviation repeatability of $\pm 2 \mu \mathrm{g}$. The daily average TSP concentration in air $\left(\mu \mathrm{g} \mathrm{m}^{-3}\right)$ per sampling period was calculated from the measured TSP load (using total hours in a period divided by 24) and the total volume of air flow through the filter. Flow rates were corrected for site elevation and temperature using the average monthly temperatures recorded during the sampling period (http://www.wrcc.dri.edu/summary/climsmco.html; accessed 18 April 2016) as described by Neff et al. (2013).

\subsection{Organic matter}

Mass of organic matter was determined by loss-on-ignition measurements conducted by heating a portion of 238 filters from the CNP, MVNP, TEL, NIW, and SGS sites to $600^{\circ} \mathrm{C}$. The organic matter mass was determined by the difference between filter mass after heating and mass of that filter before heating. The mass concentration of organic matter on each filter was determined as for TSP in $\mu \mathrm{g} \mathrm{m}^{-3}$ per sampling period and further reduced to a daily average value for a sampling period.

\subsection{Particle-size analysis for dust-on-snow samples.}

Particle-size analysis (PSA) employed a laser-light scattering method (Malvern Mastersizer) capable of measuring particles between 0.06 and 2,000 $\mu \mathrm{m}$, and the particle-size distribution (PSD) of a bulk sample was determined as volume percentages. When present, large fragments of organic matter such as insects and conifer needles were removed by hand. Samples were then prepared by digesting remaining organic matter in $30 \% \mathrm{H}_{2} \mathrm{O}_{2}$ and were deflocculated in a Na-hexametaphosphate solution. 


\subsection{Regional wind patterns and back-trajectory analysis}

Synoptic scale wind patterns were determined using the web-based Hysplit Trajectory Model (http://ready.arl.noaa.gov/HYSPLIT.php; Draxler and Hess, 2004) and archived climate and wind speed data from the Global Data Assimilation System (GDAS; https://www.ready.noaa.gov/gdas1.php). Back trajectories were run over 24 hours over the approximately two-week TSP sampling periods using the vertical velocity model algorithm with a start elevation of $100 \mathrm{~m}$ above ground level and output as a GIS point file. The average surface wind speed for each back trajectory was then estimated using the GDAS data as described by Neff et al. (2013).

\subsection{Drought and fire}

To evaluate possible controls of regional aridity on TSP concentrations, we examined annual conditions of drought across the study area and upwind regions using the Palmer Drought Severity Index by climate division (http://www.ncdc.noaa.gov/temp-and-precip/drought/historical-palmers). Fire perimeters in the study area and upwind regions that may have affected TSP concentrations were downloaded from the Geospatial Multi-Agency Coordination for Wildland Fire Support website (http://www.geomac.gov).

\subsection{Statistical analyses}

Because the IMPROVE samplers operate one out of every three days, the TSP and IMPROVE $\mathrm{PM}_{2.5}$ and $\mathrm{PM}_{10}$ concentrations could not be compared on a daily or weekly basis. Instead, the daily average particulate concentration of the TSP sampler calculated over a sampling period was compared to an daily average particulate concentration of the individual IMPROVE sampling days over the same period of time (http://vista.cira.colostate.edu/improve/). The $\mathrm{PM}_{2.5-10}$ concentration was calculated as the difference between the two-week averaged IMPROVE concentrations in the $\mathrm{PM}_{2.5}$ and $\mathrm{PM}_{10}$ size ranges. 
Similarly, concentrations of $\mathrm{PM}_{>10}$ were calculated as the difference between concentrations of TSP and $\mathrm{PM}_{10}$

The temporal covariance of daily average TSP concentrations among sites was determined with cross-correlation function in the "stats" package in the R Project for Statistical Computing (R

Development Core Team, 2015). Cross correlation determines the similarity of concentrations between two sites as a function of the lag time of one site relative to the other. We evaluated average concentrations of TSP over the approximately two-week sampling period, in addition to 30-day and 45day running averages. Relations and differences were respectively determined among different particulate size fractions $\left(\mathrm{PM}_{2.5}, \mathrm{PM}_{2.5-10}, \mathrm{PM}_{>10}\right.$, and TSP) using Pearson's correlations and analysis of variance (ANOVA). We used analysis of covariance (ANCOVA) to test whether differences existed among these size-fraction relations by season of dominant weather regime (spring Pacific frontal storms: mid-February to mid-June; summer monsoon: early July to late September; and no dominant storm pattern in fall/winter: early November to mid-February).

\section{Results}

\subsection{Particle-mass concentrations}

The dryland sites CNP, MVNP, and SGS recorded TSP concentrations mostly higher than those collected at the montane sites that are in mesic settings, have high vegetation cover, and are farther from the major dust emitting deserts (Figs. 2 - 6; Table 2; Supplementary material Table 1). 


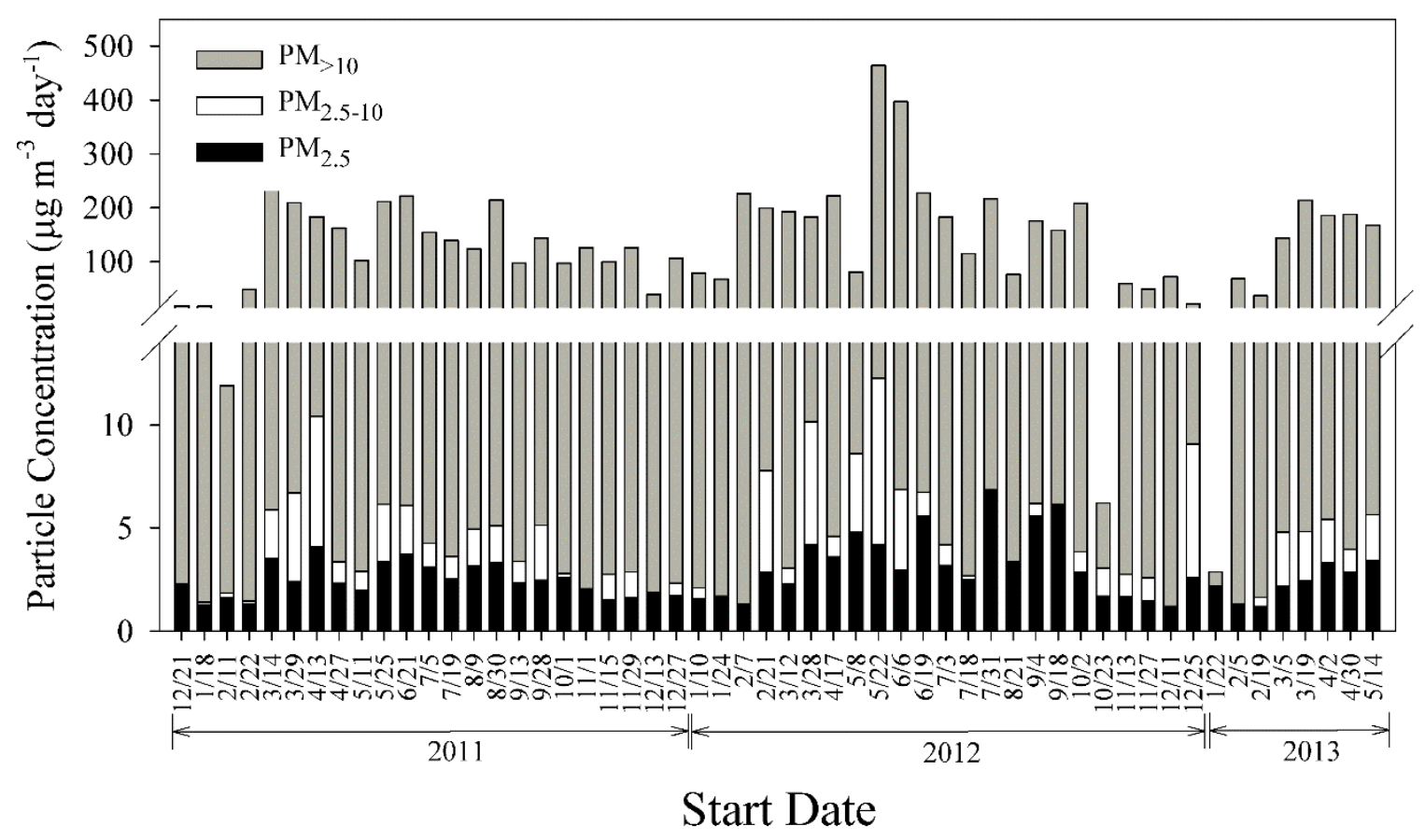

Figure 2. Average particle concentrations $\left(\mu \mathrm{g} \mathrm{m}^{-3} \mathrm{day}^{-1}\right)$ for three particulate-matter (PM) fractions $\left(\mathrm{PM}_{>10}, \mathrm{PM}_{2.5-10}, \mathrm{PM}_{2.5}\right)$ at Canyonlands National Park (Utah) over each sampling period. The start date indicates when the sampling period began.

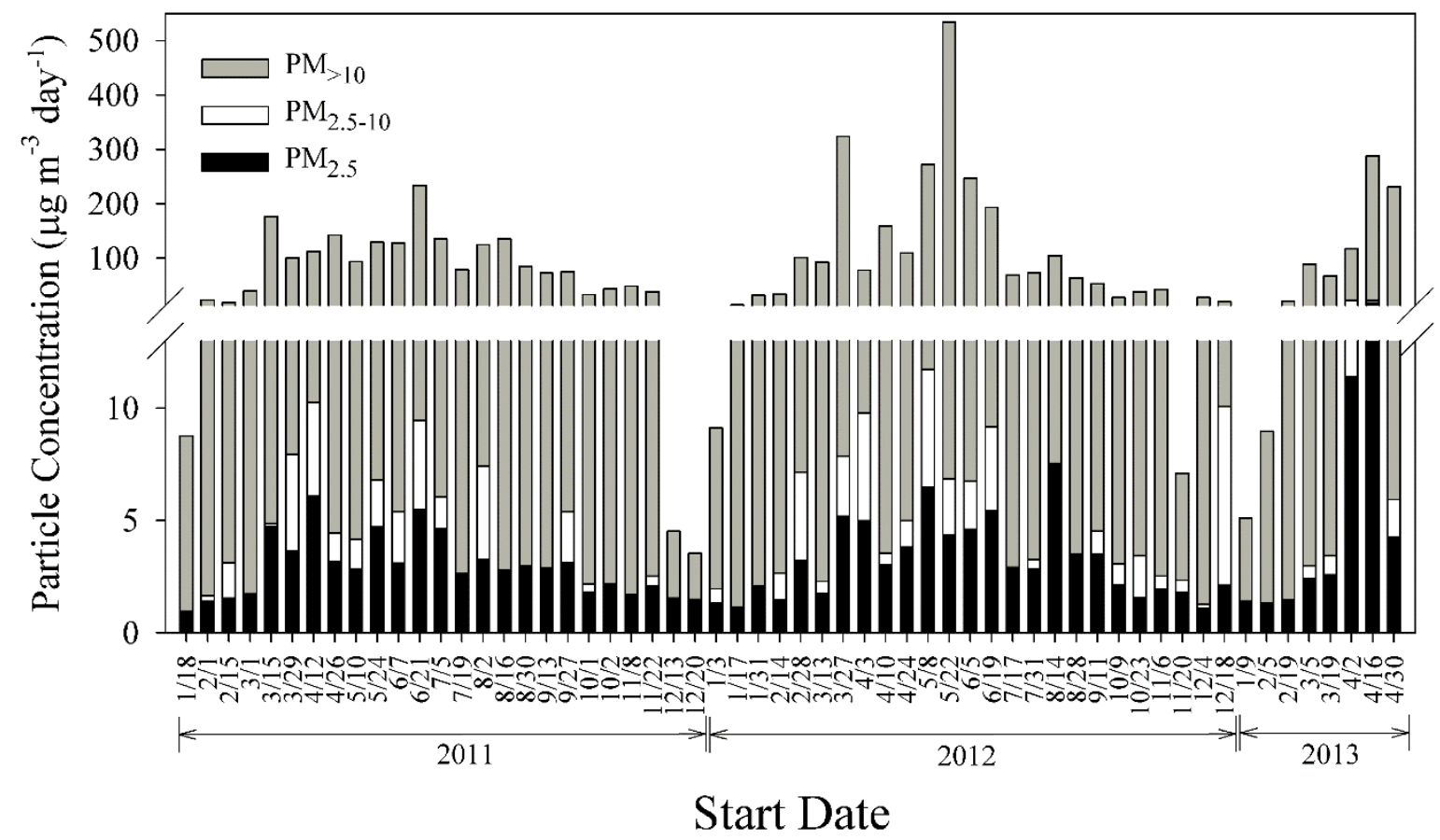


Figure 3. Average particle concentrations $\left(\mu \mathrm{g} \mathrm{m}^{-3} \mathrm{day}^{-1}\right)$ at Mesa Verde National Park (Colorado) over each sampling period. Start date and size classes as in Fig. 2.

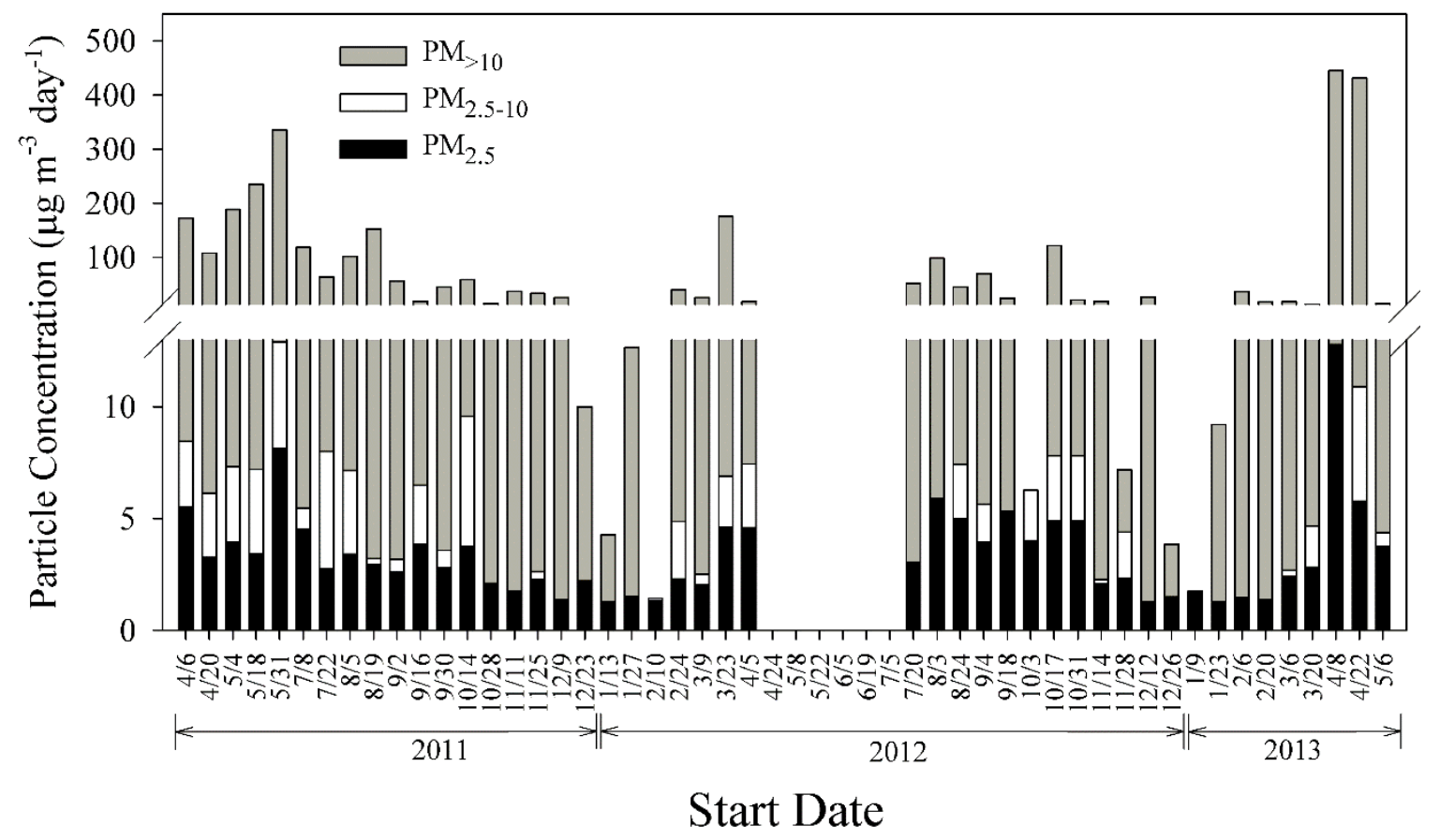

Figure 4. Average particle concentrations $\left(\mu \mathrm{g} \mathrm{m}^{-3} \mathrm{day}^{-1}\right)$ at Telluride (Colorado) over each sampling period. Start date and size classes as in Fig. 2. The gap in data between 4/5 and 7/20 (2012) was caused by equipment malfunction. 


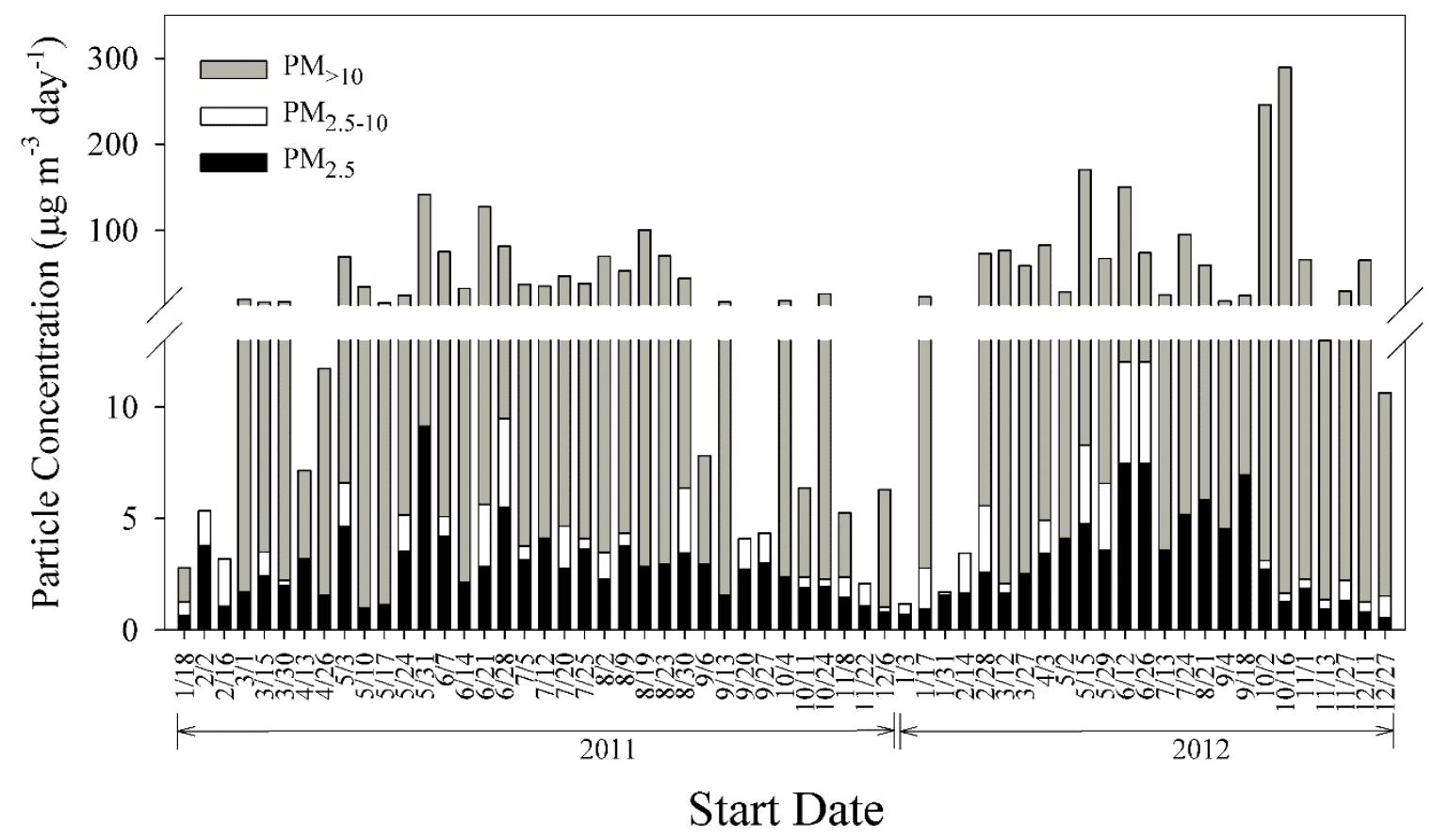

Figure 5. Average particle concentrations $\left(\mu \mathrm{g} \mathrm{m}^{-3} \mathrm{day}^{-1}\right)$ at Niwot Ridge (Colorado) over each sampling period. Start date and size classes as in Fig. 2.

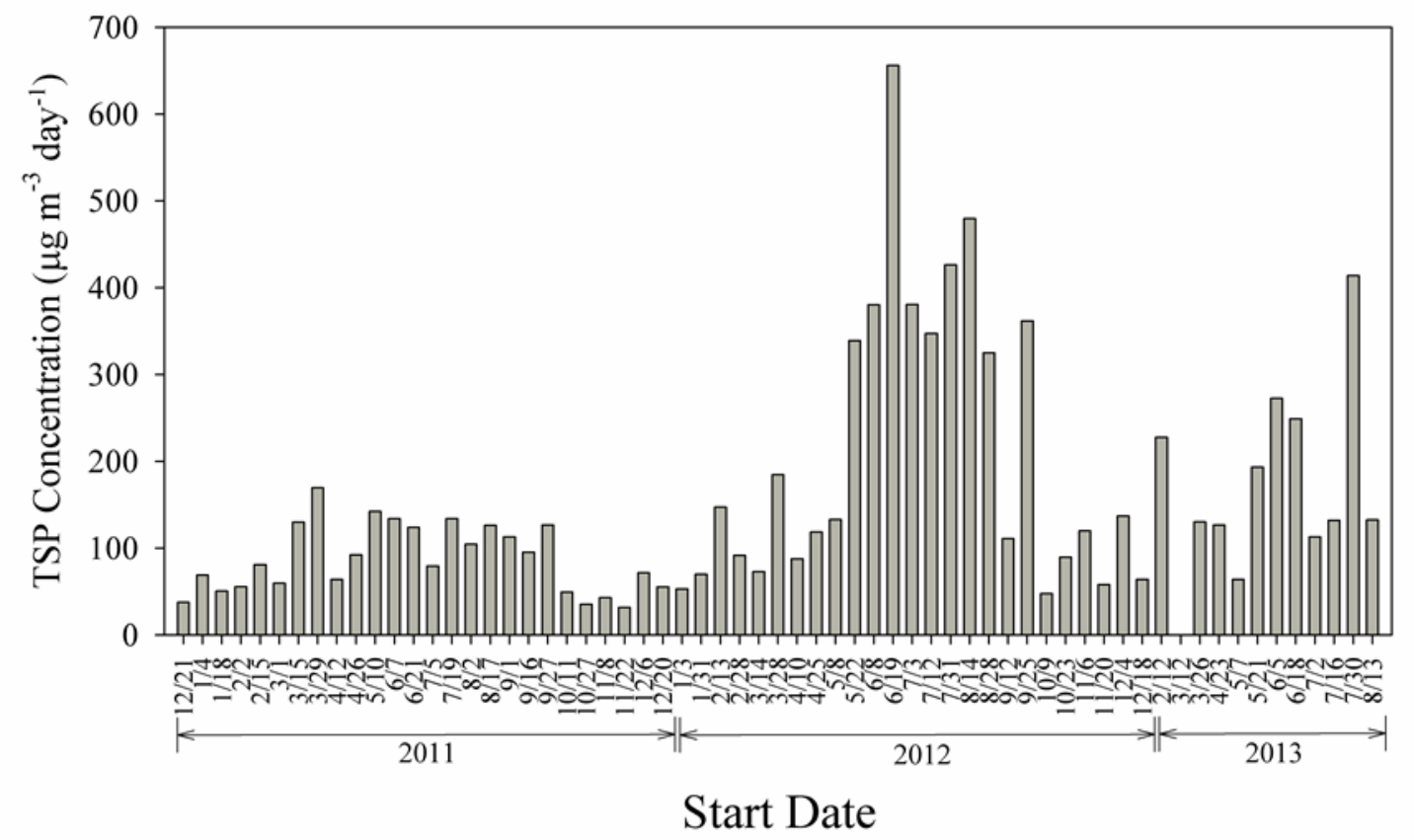

Figure 6. Average particle concentrations of TSP $\left(\mu \mathrm{g} \mathrm{m}^{-3} \mathrm{day}^{-1}\right)$ at the Shortgrass Steppe site (Colorado) over each sampling period. Start date and size classes as in Fig. 2. 
Concentrations of TSP and $\mathrm{PM}_{>10}$ differed among seasons across all sites (Figs. 2-6). Elevated TSP and $\mathrm{PM}_{>10}$ concentrations were commonly recorded for all sites from mid-February through midJune. Low TSP and $\mathrm{PM}_{>10}$ concentrations were recorded from November to mid-February, and intermediate TSP and $\mathrm{PM}_{>10}$ concentrations were typical for early July to late September (seasonal differences in TSP: $\left.\mathrm{F}=23.78, \mathrm{P}<0.0001 ; \mathrm{PM}_{10}: \mathrm{F}=22.17, \mathrm{P}<0.0001\right)$. As an overall measure of regional dust, the average TSP concentrations for the five sites were 86 and $128 \mu \mathrm{g} \mathrm{m}^{-3}$ day $^{-1}$ during 2011 and 2012, respectively. Compared with 2011, TSP concentrations during 2012 increased by 1.3 times at CNP and MVNP, by 2.0 times at NIW, and by 2.3 times at SGS (Table 2). Concentrations of TSP declined at TEL by about half from 2011 to 2012, but these data are not comparable to interannual differences at the other sites because of instrumental outages during spring to mid-summer 2012. Excluding the TEL data, the average TSP concentrations of 83 and $146 \mu \mathrm{g} \mathrm{m}^{-3}$ day $^{-1}$ for 2011 and 2012, respectively, were significantly different $\left(P=0.002 ; \mathrm{sd}=63\right.$ and $133 \mu \mathrm{g} \mathrm{m}^{-3} \mathrm{day}^{-1}$, respectively $)$. 
Table 2. Mean concentrations (standard deviations, sd) for TSP, $\mathrm{PM}_{2.5-10}$, and $\mathrm{PM}_{2.5}$, and mean organic matter (OM) concentrations (sd) in TSP filters from loss-on-ignition analyses. All values in $\mu \mathrm{g} \mathrm{m}^{-3} \mathrm{day}^{-1}$. OM \% denotes mean percent organic matter in daily average TSP concentrations. Sites: CNP, Canyonlands National Park; MVNP Mesa Verde National Park; TEL, Telluride; NIW, Niwot Ridge; SGS, Shortgrass Steppe.

$\begin{array}{cccccc}\text { Site \& Year } & \text { TSP (sd) } & \text { PM2.5-10 (sd) } & \text { PM2.5 (sd) } & \text { OM (sd) } & \text { OM \% } \\ \text { CNP 2011 } & 134(75) & 3.8(2.3) & 2.5(0.8) & 3.1(0.7) & 3.7 \\ \text { CNP 2012 } & 171(111) & 4.6(3.0) & 3.2(1.7) & 3.4(0.8) & 2.8 \\ \text { MVNP 2011 } & 94(62) & 4.1(2.7) & 3.0(1.4) & 3.4(1.0) & 6.4 \\ \text { MVNP 2012 } & 117(126) & 4.3(3.0) & 3.2(1.8) & 3.7(1.7) & 5.0 \\ \text { TEL 2011 } & 113(92) & 5.6(3.3) & 3.4(1.6) & 3.6(1.7) & 5.7 \\ \text { TEL 2012 } & 52(38) & 4.4(2.5) & 3.3(1.6) & 3.2(1.6) & 10.1 \\ \text { NIW 2011 } & 41(39) & 3.3(2.2) & 2.8(1.9) & 1.5(0.4) & 12.4 \\ \text { NIW 2012 } & 80(76) & 3.8(3.1) & 3.1(2.2) & 2.0(1.0) & 4.8 \\ \text { SGS 2011 } & 89(40) & & & 2.7(0.7) & 3.5 \\ \text { SGS 2012 } & 204(168) & & & 3.1(1.3) & 2.0\end{array}$

Daily TSP concentration averages were significantly correlated among dryland sites $(\mathrm{r}=0.40-$ 0.77; Table 3). Concentrations between sites had the highest correlation at zero-lag (the same time interval), suggesting nearly synchronous TSP accumulation among sites, at least within sampling durations of about two weeks. Similar correlations emerged for the 30-day and 45-day averages. The $14-45$ day TSP average loadings at the montane sites, about 300-km apart, were also correlated $(\mathrm{r}=$ $0.69-0.72$ ). This association reflects similar variations in dust loading on a seasonal basis, despite having mostly dissimilar average daily loadings on an annual basis (Table 2, but noting again a sampling break at the TEL site). 
Table 3. Zero-lag correlations between the running-average (across 14-days, 30-days, and 45-days) of TSP concentrations between site pairs. CNP, Canyonlands National Park; MVNP, Mesa Verde National Park; TEL, Telluride; NIW, Niwot Ridge; SGS, Shortgrass Steppe. Bold values indicate significant correlations $(P<0.05)$.

\begin{tabular}{cccccc} 
14-Day & & & & & \\
& CNP & MVNP & TEL & NIW & SGS \\
CNP & - & $\mathbf{0 . 7 7}$ & $\mathbf{0 . 4 3}$ & $\mathbf{0 . 3 8}$ & $\mathbf{0 . 4 8}$ \\
MVNP & - & - & $\mathbf{0 . 6 8}$ & $\mathbf{0 . 7 5}$ & $\mathbf{0 . 4 0}$ \\
TEL & - & - & - & $\mathbf{0 . 7 2}$ & 0.29 \\
NIW & - & - & - & - & $\mathbf{0 . 4 3}$ \\
SGS & - & - & - & - & - \\
& & & & & \\
30-Day & & & & & \\
\hline & CNP & MVNP & TEL & NIW & SGS \\
CNP & - & $\mathbf{0 . 7 7}$ & $\mathbf{0 . 4 8}$ & $\mathbf{0 . 3 7}$ & $\mathbf{0 . 5 5}$ \\
MVNP & - & - & $\mathbf{0 . 6 8}$ & $\mathbf{0 . 7 4}$ & $\mathbf{0 . 4 1}$ \\
TEL & - & - & - & $\mathbf{0 . 6 9}$ & 0.24 \\
NIW & - & - & - & - & $\mathbf{0 . 4 2}$ \\
SGS & - & - & - & - & - \\
& & & & & \\
$45-D a y$ & & & & & \\
CNP & CNP & MVNP & TEL & NIW & SGS \\
MVNP & - & $\mathbf{0 . 7 7}$ & $\mathbf{0 . 6 1}$ & $\mathbf{0 . 3 6}$ & $\mathbf{0 . 6 0}$ \\
TEL & - & - & $\mathbf{0 . 7 0}$ & $\mathbf{0 . 6 9}$ & $\mathbf{0 . 3 8}$ \\
NIW & - & - & - & $\mathbf{0 . 6 9}$ & 0.21 \\
SGS & - & - & - & - & $\mathbf{0 . 3 5}$ \\
& & & & - & -
\end{tabular}

Each site recorded elevated daily average TSP concentrations greater than $185 \mu \mathrm{g} \mathrm{m}^{-3}$ during at least one sampling period in 2011 and 2012 (Figs. 2 - 6; Supplementary material Table 1). This concentration, an arbitrary but convenient cutoff for comparisons among sites, was exceeded during 17 sampling periods at CNP, eight periods at MVNP, five periods at TEL, three periods at NIW, and nine periods (all during 2012) at SGS. Maximum daily TSP loadings for the bi-monthly collection periods reached levels of $700 \mu \mathrm{g} \mathrm{m}^{-3}$ at the CNP site in 2010 (4/20 - 4/28; Neff et al., 2013). Because dust events typically last $1-2$ days in the western interior U.S. 
(http://gec.cr.usgs.gov/projects/sw/dust_detection/, accessed 18 April 2016; Jewell and Nicoll, 2011; Steenburgh; et al., 2012; Hahnenberger and Nicoll, 2012; Lei and Wang, 2014), the average daily TSP concentrations calculated here over an approximately two-week period must be considerably lower than 24-hour concentrations for TSP during high-concentration events.

\subsection{Comparisons among concentrations of particle-size classes}

During the 2011-2012 study period, the mean TSP concentration $\left(106 \mu \mathrm{g} \mathrm{m}^{-3}\right.$ day $^{-1}$; standard deviation [sd] $=105 \mu \mathrm{g} \mathrm{m}^{-3} \mathrm{day}^{-1}$ ) from all TSP filters was consistently elevated compared with mean concentrations of the fine $\mathrm{PM}_{2.5}$ and coarse $\mathrm{PM}_{2.5-10}$ fractions. The annual mean concentrations of $\mathrm{PM}_{2.5-}$ ${ }_{10}$ at CNP and MVNP (dryland sites, closest to major dust sources) averaged $4.2 \mu \mathrm{g} \mathrm{m}{ }^{-3} \mathrm{day}^{-1}$ ( $\mathrm{sd}=2.7 \mu \mathrm{g}$

$\mathrm{m}^{-3}$ day $^{-1}$ ), mostly higher than concentrations at montane sites TEL and NIW (mean, $4.1 \mu \mathrm{g} \mathrm{m}^{-3}$ day $^{-1}$, $\mathrm{sd}=2.7 \mu \mathrm{g} \mathrm{m}^{-3}$ day $^{-1}$ ). Concentrations of $\mathrm{PM}_{2.5}$ were nearly the same at CNP and MVNP (mean=2.9 $\mu \mathrm{g}$ $\mathrm{m}^{-3} \mathrm{day}^{-1}, \mathrm{sd}=1.5 \mu \mathrm{g} \mathrm{m}^{-3} \mathrm{day}^{-1}$ ) as at montane sites (mean $=3.1 \mu \mathrm{g} \mathrm{m}^{-3} \mathrm{day}^{-1}, \mathrm{sd}=1.7 \mu \mathrm{g} \mathrm{m}^{-3}$ day $^{-1}$ ) (Supplementary material Table 1). There were higher concentrations of fine and coarse modes relative to $\mathrm{PM}_{>10}$ at the TEL and NIW sites compared to the lower elevation CNP and MVNP sites (ANCOVA test of differences in slopes for the fine fraction: $F_{3,145}=7.77, \mathrm{P}<0.0001$; for the coarse fraction: $\mathrm{F}_{3,145}=$ 2.93, $\mathrm{P}<0.05)$. Across all sites, $\mathrm{PM}_{>10}$ concentrations corresponded positively with the $\mathrm{PM}_{2.5}$ fine- $(\mathrm{r}=$ $0.59-0.77$, all $\mathrm{P}<0.001)$ and $\mathrm{PM}_{2.5-10}$ coarse-mode $(\mathrm{r}=0.50-0.75$, all $\mathrm{P}<0.0001)$ concentrations regardless of the season (Fig. 7). 


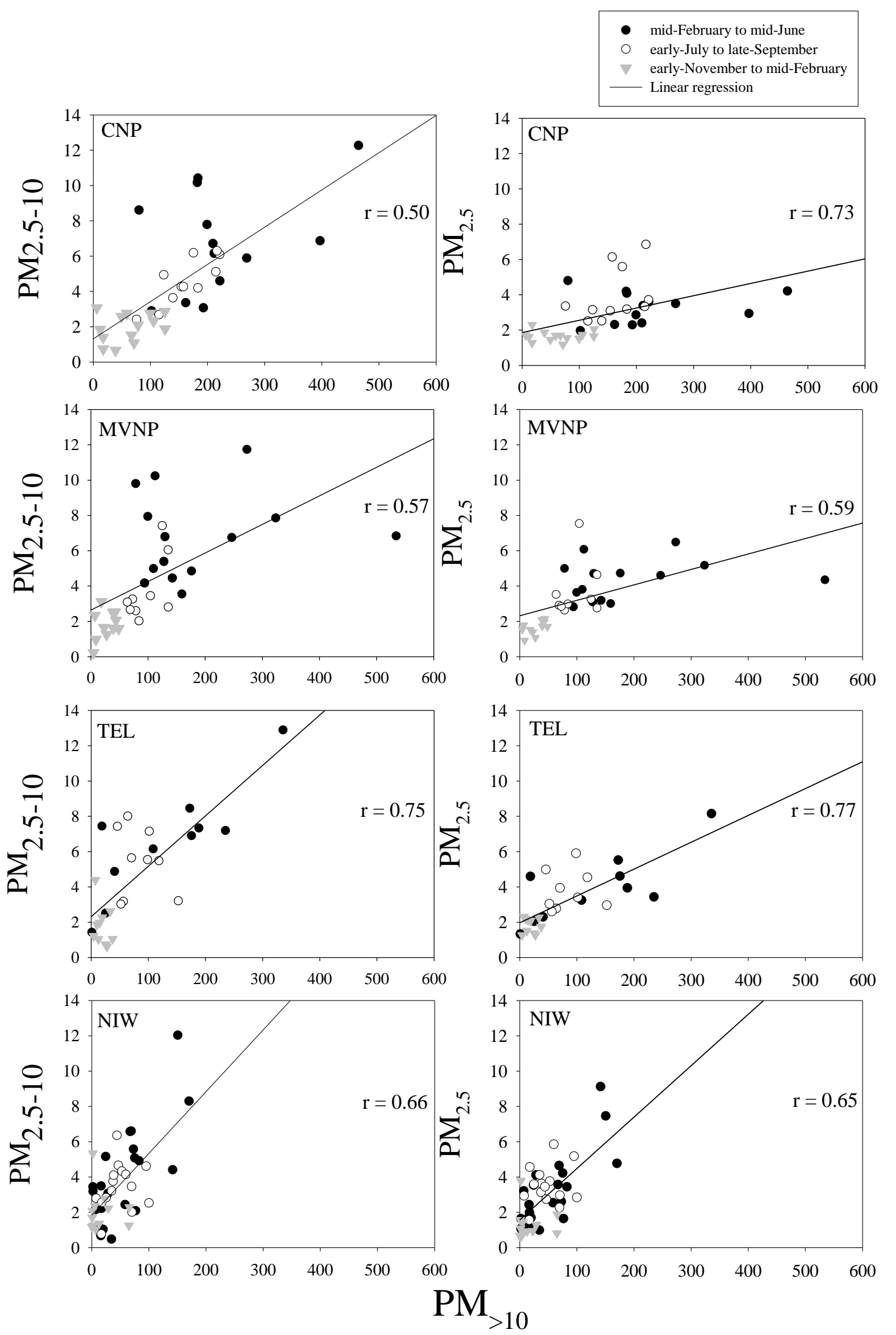


Figure 7. Relations between $\mathrm{PM}_{2.5-10}$ (coarse) and $\mathrm{PM}_{>10}$ concentrations (left panel) and between $\mathrm{PM}_{2.5}$ and $\mathrm{PM}_{>10}$ concentrations (right panel) at the Canyonlands National Park (CNP), Mesa Verde National Park MVNP), Telluride (TEL), and Niwot Ridge (NIW) sites by season (mid-February to mid-June, early-July to late-September, and early-November to mid-February). Significant correlations coefficients (r) are shown for all seasons combined.

\subsection{Organic matter concentrations determined by loss on ignition}

Annual mean concentrations of organic matter in the TSP filters at each site were $<4 \mu \mathrm{g} \mathrm{m}^{-3} \mathrm{day}^{-1}$ with little variation (Table 2). Organic matter concentrations (Supplementary material Fig. 1) were similar among the three westernmost sites (CNP, MVNP, TEL; 3.1-3.7 $\mu \mathrm{g} \mathrm{m}^{-3}$ day $^{-1}$ ) and were also comparable to the SGS-site annual means $\left(2.7 \mu \mathrm{g} \mathrm{m}^{-3}\right.$ day $^{-1}$ in $2011 ; 3.1 \mu \mathrm{g} \mathrm{m}^{-3}$ day $^{-1}$ in 2012$)$. Site means were least in the forested NIW site $\left(1.5 \mu \mathrm{g} \mathrm{m}^{-3}\right.$ day $^{-1}$ in $2011 ; 2.0 \mu \mathrm{g} \mathrm{m}^{-3}$ day $^{-1}$ in 2012$)$. Organic matter at these sites thus composed a very small portion of TSP concentrations, mostly between 2 and 6 percent.

\subsection{Regional wind trajectories}

Patterns of regionally dominant winds are exemplified in back-trajectories for the five sites that illustrate dominant strong wind directions across the study region and recognized source regions (Figs. 8, 9, 10; Supplementary material Table 2). 


\section{Canyonlands 0511-052511}

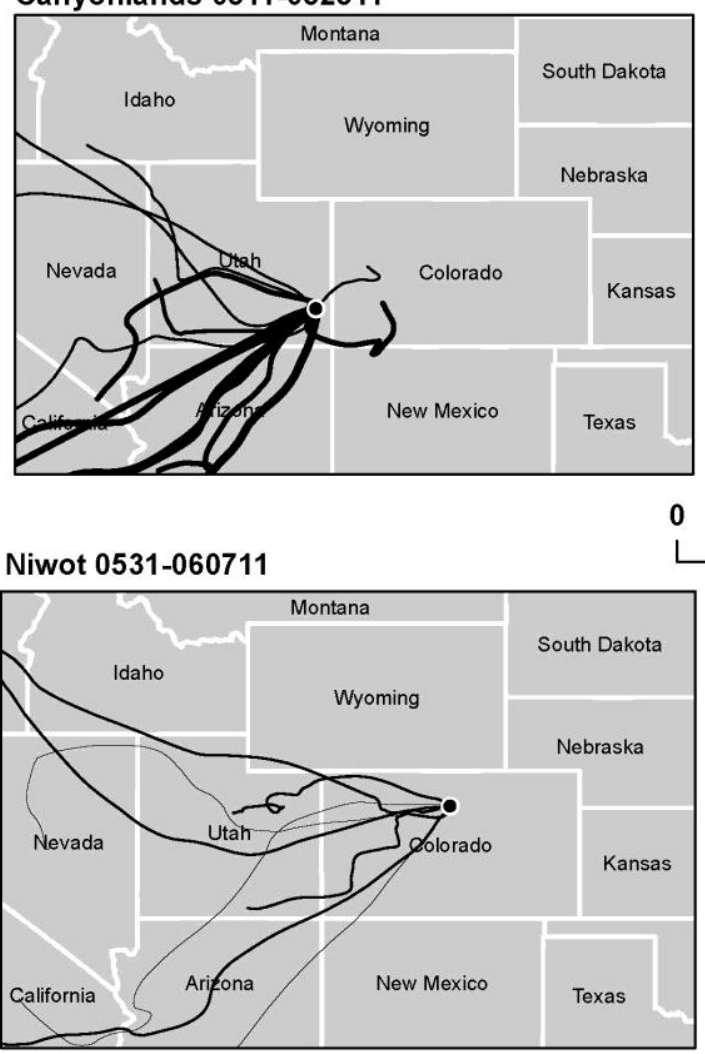

Mesa Verde 0510-052411

- Locations Wind Speed $(\mathrm{m} / \mathrm{s})$ endWNSP

$1.00-3.00$

$3.01-6.00$

$6.01-8.00$

$8.01-10.00$

$10.01-12.00$

$12.01-16.00$

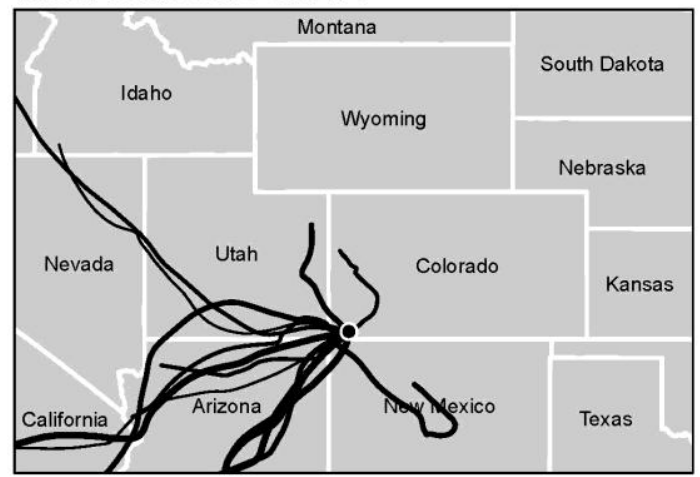

$800 \mathrm{Km}$

Telluride 0531-060711

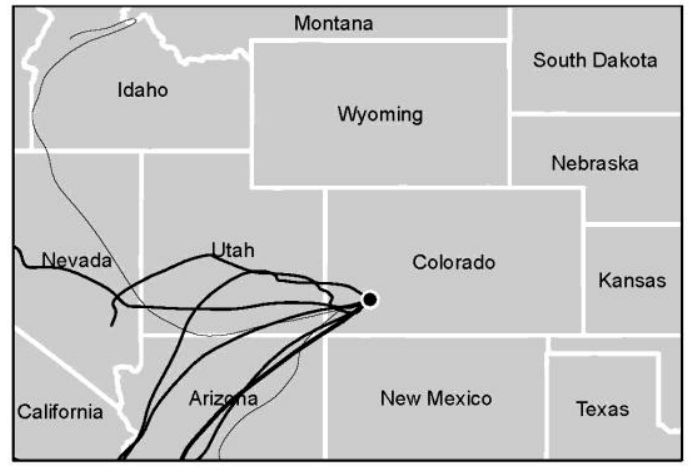

Figure 8. Back-wind trajectories for indicated time periods (e.g., May 11, 2011 to May 25, 2011 is denoted by 0511-052511) derived from the Hysplit model for four TSP sites (Canyonlands National Park, Mesa Verde National Park, Niwot Ridge LTER, Telluride). The widths of the lines represent the average wind speed along the course of the trajectories. 
Canyonlands 0522-060512

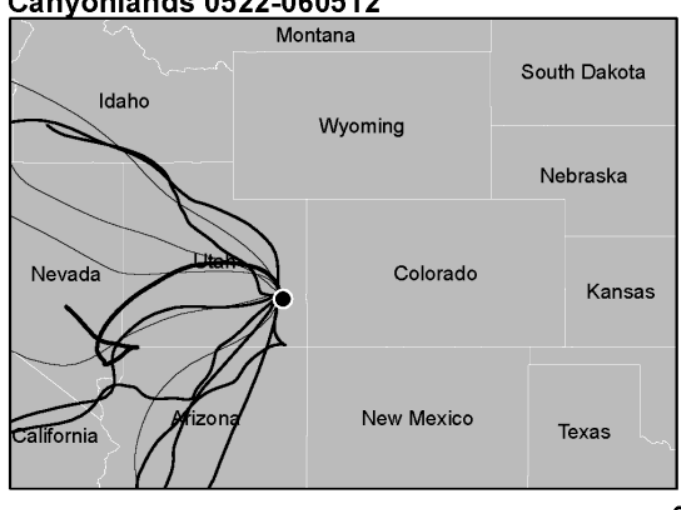

Niwot 0515-052912

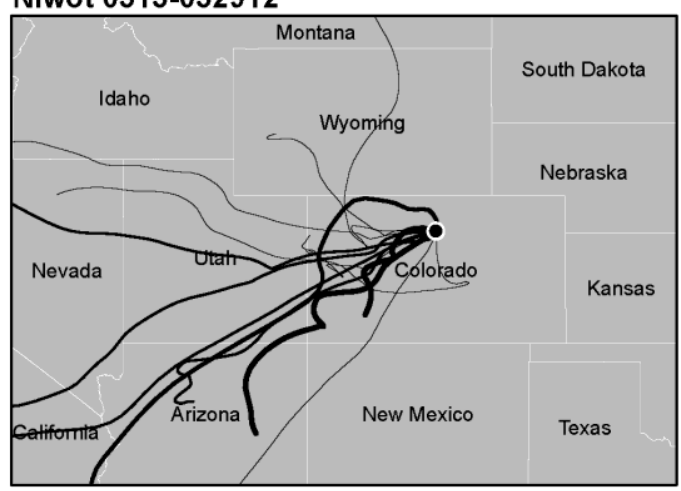

Mesa Verde 0522-060612

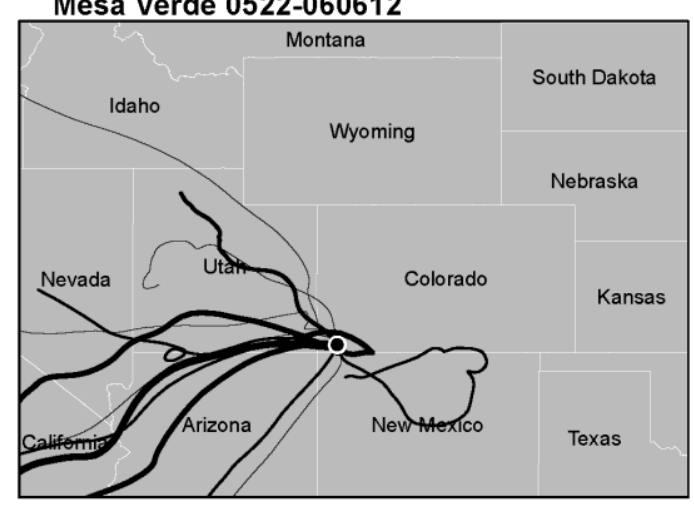

$800 \mathrm{Km}$

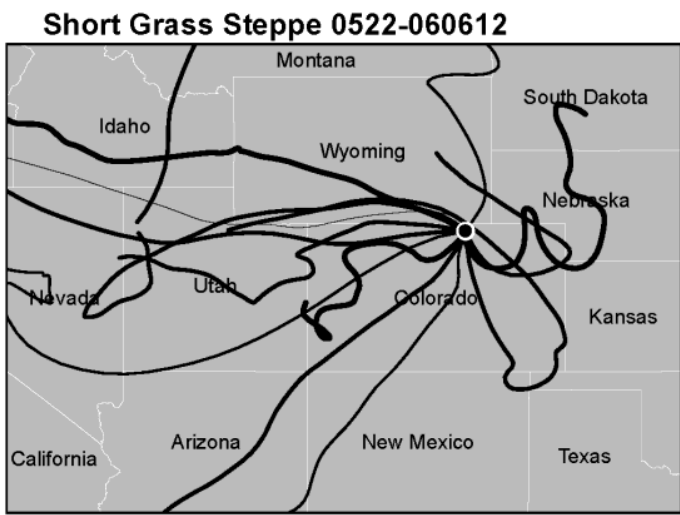

Figure 9. Twenty-four hour back trajectories for indicated time periods (e.g., May 22, 2012 to June 5, 2012 is denoted by 0522-060512) derived from the Hysplit model for four TSP sites (Canyonlands National Park, Mesa Verde National Park, NIW = Niwot Ridge LTER, Short Grass Steppe $=$ SGS). The widths of the lines represent the average wind speed along the course of the trajectories. 


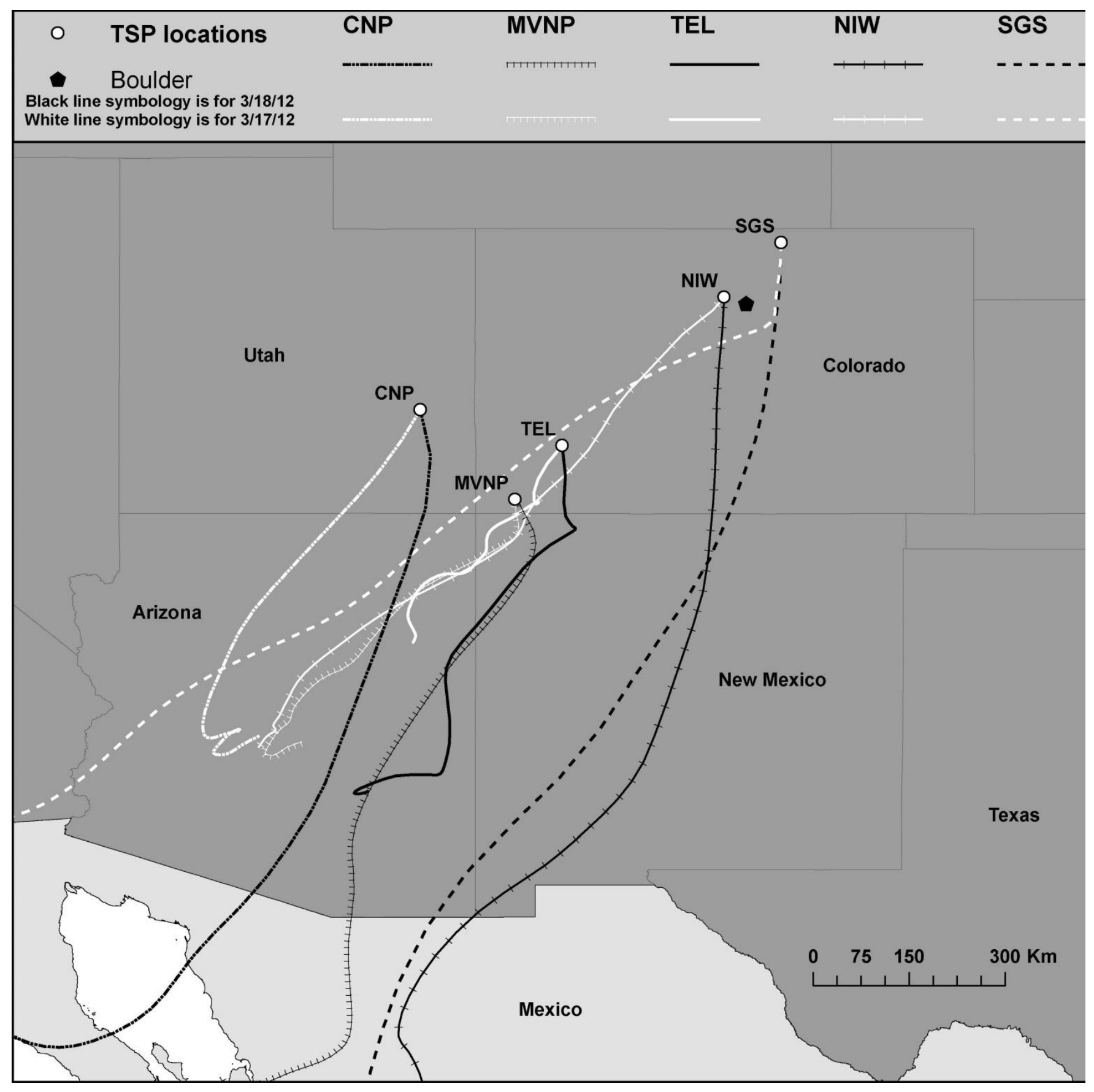

Figure 10. Twenty-four hour back wind trajectories on March 17 (white lines) and 18 (black lines), 2012 from the Hysplit model for five TSP sites $(\mathrm{CNP}=$ Canyonlands National Park, MVNP = Mesa Verde National Park, TEL = Telluride, CO, NIW = Niwot Ridge LTER, SGS = Shortgrass Steppe). 
The time intervals for these analyses were chosen because they were periods of high TSP deposition during the typically windy spring and early summer seasons as stated previously. For each site, many of the trajectories swept from the southwest across the southern Colorado Plateau, primarily through northeastern Arizona and northwestern New Mexico and also from the west across the central Colorado Plateau. Trajectories from the northwest were also apparent, some of them associated with strong winds. In addition, northerly trajectories strongly intersected the Shortgrass Steppe site (SGS) and also weakly intersected the montane NIW site in 2011 (Fig. 9).

\subsection{Particle-size analysis}

In DOS layers, $78-95 \%$ of particles were silt size and smaller (PM $<63 \mu \mathrm{m})$. With one exception, median particle sizes generally decreased (30 to $17 \mu \mathrm{m})$ from west to east, and the average median size was $21 \mu \mathrm{m}$. Considering nine of 10 DOS sites, the proportions of $\mathrm{PM}_{10}$ relative to all TSP increased from $17 \%$ to $33 \%$ with distance from the MVNP site (Fig. 11). (The MVNP site was chosen for a starting location because dust plumes have been commonly observed to pass across this site (1) in satellite retrievals (http://gec.cr.usgs.gov/projects/sw/dust_detection/), (2) by eye-witnesses (P.

Bohmann and G. San Miguel, both MVNP, pers. comm., 2010), and (3) in day-time digital camera images collected at 15-minute intervals since March 2011 (http://gec.cr.usgs.gov/projects/regional_cams/index.html, accessed 18 April 2016; http://gec.cr.usgs.gov/projects/sw/dust_detection/). The exception to the trends in particle sizes was the DOS sample at the SASP site near Silverton, CO that contained the highest amount of $\mathrm{PM}_{10}$ compared to all sites. The reasons for this discrepancy are unknown but may be related to the high elevation $(3,370$ m) and aspect (northeast-facing) of the SASP site that might favor more particle-size sorting than at the other DOS sites. 


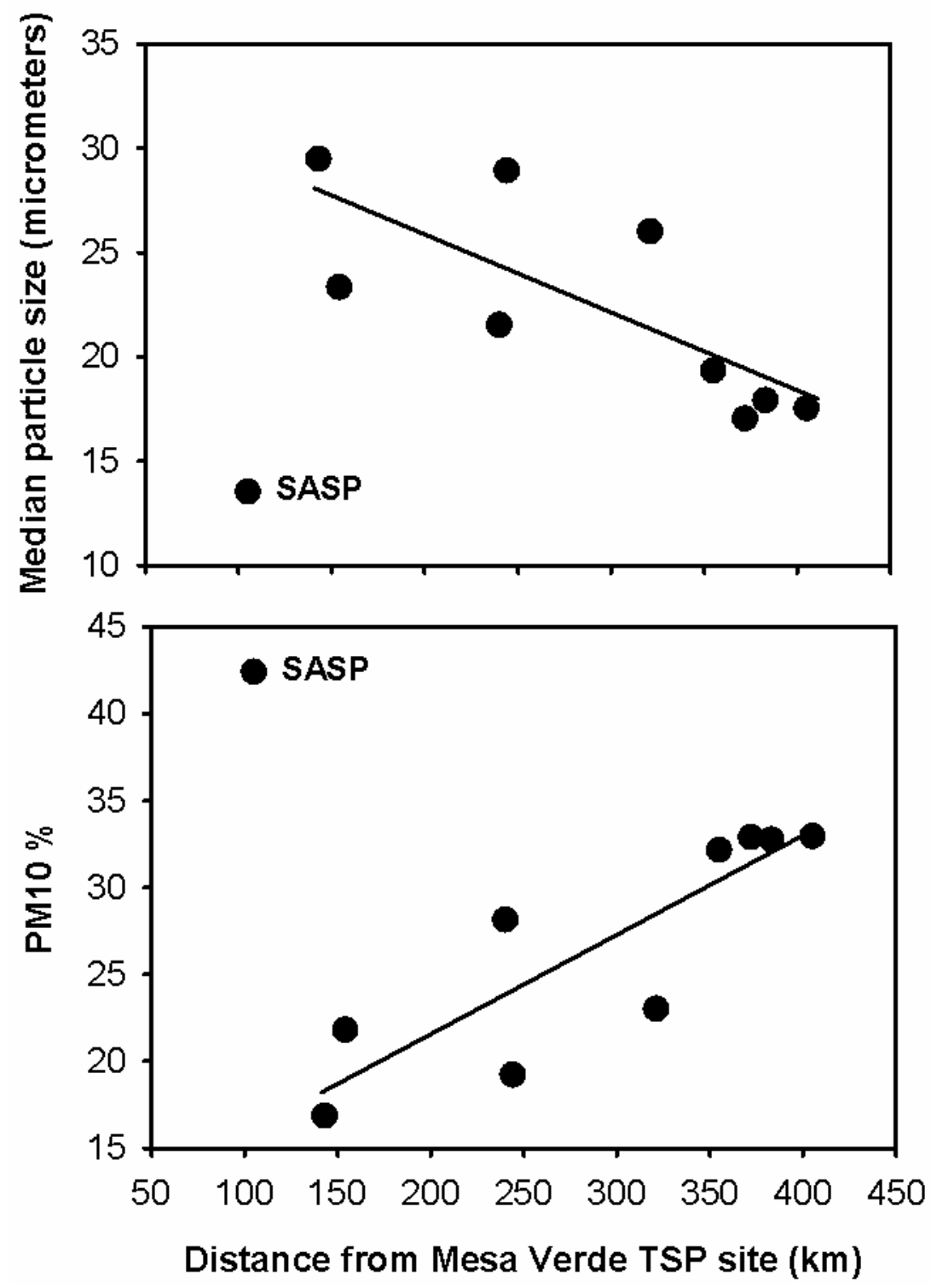

Figure 11. Particle-size parameters of dust-on-snow (DOS) samples with distance from the Mesa Verde TSP site. Top, median particle size. Bottom, $\mathrm{PM}_{10}$ percentage. SASP, DOS sample close to Silverton (Fig. 1). Omission of SASP results produces regression lines with $\mathrm{r}^{2}=0.58$ for median size and $\mathrm{r}^{2}=0.74$ for $\mathrm{PM}_{10}$ percent. The rationale for omitting SASP data is given in the text.

\subsection{Regional aridity and fire}


In 2011, the Palmer Drought Severity Index (PDSI) was above average (2.0 to 4.0) in the upwind region (central Utah) to the west of the TSP sites and below average (-2.0 to -3.0) to the southwest (Supplementary material Fig. 2). Several moderate-sized (400 to 3,000 ha.) fires occurred to the west and southwest of the TSP sites, but the largest June - early July fires were far to the south (Wallow Fire; 218,000 ha) and southeast (Las Conchas Fire, 63,000 ha), so that their plumes largely missed TSP sites as indicated on available satellite retrievals during the fires (http://earthobservatory.nasa.gov/NaturalHazards/view.php?id=50952; http://earthobservatory.nasa.gov/NaturalHazards/view.php?id=51210 both accessed 18 April 2016). In 2012, PDSI was far below average (-3.0 to $-4.0+)$ to the upwind west and southwest of the TSP sites, and several large fires (19,000 to 44,000 ha) burned to the west of the TSP sites. Most notably among these, the High Park Fire (35,000 ha; June 9-30) was $42 \mathrm{~km}$ southwest of the SGS site (Supplementary material Fig. 2).

\section{Discussion}

The TSP concentrations in filters collected at about two-week intervals compared with simultaneously measured $\mathrm{PM}_{10}$ and $\mathrm{PM}_{2.5}$ concentrations showed that elevated concentrations of large mineral particles $\left(\mathrm{PM}_{>10}\right)$ drove high concentrations of TSP in regional dust across part of the western interior U.S. during 2011 and 2012. Among the highest TSP concentrations were those measured during late winter through spring, the period when regional dust storms and events are frequent. Furthermore, the correlative analysis strongly suggests that a large fraction of the coarse $\left(\mathrm{PM}_{2.5-10}\right)$ and fine fractions $\left(\mathrm{PM}_{2.5}\right)$ were also generated during regional dust events.

\subsection{Concentrations of particulate matter and relations to regional environmental conditions}


Across the large area encompassed by the TSP sampling network, concentrations of airborne total suspended particulate (TSP) averaged about $106 \mu \mathrm{g} \mathrm{m}^{-3}$ day $^{-1}$ during 2011 and 2012, greatly exceeding the annual average $\mathrm{PM}_{<2.5}$ and $\mathrm{PM}_{2.5-10}$ concentrations commonly by factors of 20 to $>100$. These results indicate the dominance of large $\left(\mathrm{PM}_{>10}\right)$ particles in TSP concentrations across this region (Fig. 7). The overwhelming abundance of mineral particles in the TSP fraction is demonstrated by low amounts of organic matter. These results accord with particle-size distributions in the TSP fraction at the CNP site from a prior study (Neff et al., 2013) that did not account for organic matter concentrations. The mass estimates of TSP could be influenced by the presence of very large (and heavy) sand-size particles in the sampler. However, the consistent patterns in particle-size distribution in snowpack across this region, the consistently elevated concentrations across all sites (and in regions that are covered in snow for much of the sampling period), and the prior work analyzing particle-size distributions at CNP (Neff et al., 2013) all indicate that the most likely cause of these high mass concentrations of TSP is the presence of silt-size particles between 10 and $63 \mu \mathrm{m}$. One possible exception to this pattern is the SGS site where larger particles may have contributed locally to high concentrations during the spring - fall seasons.

Among sites, location was a primary control on differences in concentrations, with much higher concentrations at the relatively low-elevation, dryland sites compared with the two montane sites (Table 2). Within sites, seasonality was a primary control on variations in TSP concentrations. Strong correlations of TSP concentrations between sites over the same time intervals suggests that dust deposition was generally related to the same weather systems that commonly traversed widespread dustsource regions. In relation to regional meteorology, the strongest dust-producing storms occur during late winter through spring with the passage of low-pressure troughs in Pacific frontal systems that commonly sweep onshore from the Pacific Ocean and eastward across drylands of the southwestern 
U.S., including the Mojave Desert, the southern Great Basin Desert, and the southern and central Colorado Plateau (Orgill and Sehmel, 1977; Changery, 1983; Brazel and Nickling, 1987; Clow et al., 2009; Urban et al., 2009; Neff et al., 2013). Such regional scope of dust transport and deposition is documented by satellite retrievals (http://gec.cr.usgs.gov/projects/sw/dust_detection/; http://earthobservatory.nasa.gov/IOTD/view.php?id=37791 accessed 18 April 2016) and records of dust fall in downwind snow cover (http://snowstudies.org/CODOS; accessed 18 April 2016). The patterns of TSP deposition are elucidated by back-trajectory analysis (Figs. 8, 9, 10). The few examples shown here are among many such examples of back trajectories and other climatological phenomena recently presented to document the regional winds that influence dust transport and aeolian activity in the western interior U.S. (Jewell and Nicoll, 2011; Steenburgh et al., 2012; Hahnenberger and Nicoll, 2012; Neff et al., 2013; Skiles et al., 2015; Axson et al., 2016). As one example, the March 17-18, 2012 dust event affected the entire network on the basis of back-trajectory analysis (Fig. 10), its record as dust-onsnow event at Silverton (http://snowstudies.org/CODOS), and its presence as a thick dust haze along the eastern slope of the Rocky Mountains near the NIW and SGS sites (Supplementary material Fig. 3). As another example, dust activity during May 23-26, 2012 can be unequivocally assigned to the high amounts of dust simultaneously deposited at CNP, MVNP, TEL, and San Juan Mountains snow cover near Silverton (http://gec.cr.usgs.gov/projects/sw/dust_detection/; http://snowstudies.org/dust/2012_FinalReport_print.pdf/; accessed 18 April 2016). Altogether, the observations of dust generation and transport reveal the importance of dust-emission events to the west and southwest of the study area that are capable of producing large amounts of particles $>10 \mu \mathrm{m}$. Consistent with this interpretation are the plots of DOS particle-size parameters against distance from the MVNP site that suggest decreasing particle sizes downwind from these major dust-source regions (Fig. 11; see also Routson et al., 2016). The Great Plains SGS and montane NIW sites additionally 
collected dust from other sources compared to the rest of the sites, with winds from the north and east on the basis of back-trajectory analysis (Fig. 9).

Strong downdrafts in front of advancing convective storms during the summertime North American Monsoon can also produce atmospheric dust (Lei and Wang, 2014). Although individual convective storms may have a small footprint relative to regional storms, recurrent and widely distributed haboobs can cumulatively have broad effects across the Colorado Plateau and the Sonoran Desert, south of the Plateau (Carleton, 1987). Evidence for such likely effects is seen in sometimes high but variable TSP concentrations at sites CNP and MVNP during summer (Figs. 2, 3).

The positive correspondence between the concentrations of the $\mathrm{PM}_{>10}$ and coarse $\left(\mathrm{PM}_{2.5-10}\right)$ fractions at the CNP, MVNP, and TEL sites indicates transport of these fractions together, especially during the late winter through spring and during the summer. Importantly, IMPROVE data at these sites revealed higher concentrations of the coarse fraction relative to those of the fine fraction $\left(\mathrm{PM}_{2.5}\right)$ during late winter-early spring compared with other collections (by $42 \%$ at CNP, $25 \%$ at MVNP, and $31 \%$ at TEL; little difference at NIW). This finding further supports the interpretation that a large proportion of the coarse fraction originated from regional dust sources. In addition, the similar positive association between the $\mathrm{PM}_{>10}$ and fine fractions implies strongly that some $\mathrm{PM}_{2.5}$ at the $\mathrm{CNP}, \mathrm{MVNP}$, and TEL sites was also generated at regional dust sources. These results are consistent with previous studies indicating the presence of fine- and coarse-fraction particles in regional dust (Claiborne et al., 2000; Park et al., 2007; Wells et al., 2007; Jugder et al., 2014).

Organic matter concentrations in TSP collected from late spring through late summer were high relative to other times. During the spring and summer, mineral dust may be mixed with a variety of organic materials including wildfire ash, pollen, and (or) other forms of windblown plant materials. Evidence for a wildfire-ash origin for some organic matter in TSP comes from the connection between 
the 2012 High Park Fire and high organic matter values at the nearby, downwind SGS site while the fire was active. Otherwise, evidence is lacking for specific contributions of wildfire ash to TSP loads, although the two-week sampling period in this study may have been too long to capture variations in sources and wind directions associated with fires (cf. Park et al., 2006). More generally, the relatively low organic matter content ( $<7$ weight percent on average) indicates that the bulk of the material in the dust samples was mineral in origin.

Over the region, we found significantly higher TSP concentration during 2012 than 2011, and many factors may have been responsible for this interannual difference. Firstly, more widespread and more intense aridity occurred in dryland areas commonly upwind from the TSP network during 2012 compared with 2011. Direct effects of soil aridification on dust emission and indirect effects mediated through diminished cover of perennial vegetation have been documented in much of this upwind region (Belnap et al., 2009; Munson et al., 2011). Secondly, changes in the intensities of cropping and grazing practices may have contributed to the variable summer TSP concentrations at the Shortgrass Steppe (SGS) site. The immediate area around this site has been moderately grazed, and it experiences other small disturbances, such as prairie-dog activity, that can diminish perennial vegetation and expose bare ground for variable periods of time (Munson and Lauenroth, 2009; Reynolds, 2010; http://esp.cr.usgs.gov/projects/sw/previous/swdust/prairie_dog_dust.html, accessed 10 June 2016). Dryland winter wheat-fallow fields, which emit dust, are present throughout the broader footprint of the SGS site. The cropped areas are most vulnerable to wind erosion during the early spring when winds are high, during harvesting between June and late July, and during planting between September and mid-October. Winter wheat yields in Colorado were lower in $2012\left(2,105 \mathrm{~kg} \mathrm{ha}^{-1}\right)$ compared to 2011 $\left(2,562 \mathrm{~kg} \mathrm{ha}^{-1}\right)$ despite more area planted (983,000 ha. in 2012, 928,000 ha. in 2011; USDA, 2015). These factors are consistent with lower soil moisture and more bare ground, and they likely indicate 
greater susceptibility to wind erosion during 2012 than during 2011. Other possible causes for interannual differences in TSP concentration, such as variable wind speeds associated with variable storm tracks, are topics for further study.

\subsection{TSP, $P M_{>10}, P M 2.5-10$, and PM2.5 concentrations-implications for air quality}

The TSP data presented here show that mineral-dust emission and deposition can occur during any month within the western interior U.S. (see also Neff et al., 2013). Moreover, our measurements and observations suggest seasonally large and ongoing effects of dust-event activity in the western interior U.S. on regional air quality. Firstly, air pollution can be caused by high concentrations of desert dust (all particle sizes; see also Hand et al., 2011, 2012; Lei and Wang, 2014; Huang et al., 2015) carried by regional winds. Secondly, standard air-quality measurements for $\mathrm{PM}_{2.5}$ and $\mathrm{PM}_{10}$ do not capture the large majority of mineral particulate pollution in this region (cf. Wells et al., 2007). These findings expand those of a precursor study of TSP at the CNP and MVNP sites (Neff et al., 2013) to encompass regional dust deposition over a much larger distance across downwind mountain ranges to the semi-arid Great Plains with dust inputs from more sources.

In a global context, concentrations of TSP in this study are similar to those reported in many African and Asian cities that are commonly affected by regional dust storms (Xiao and Liu, 2004; Ozer et al., 2006). Daily average TSP concentrations that we measured across a large swath of the western interior U.S. have exceeded TSP concentrations in more than half of the 118 large cities reported by Baldasano et al. (2003). It is problematic to compare in detail our results with data from other studies of TSP because of differences in objectives, sampling protocols, analyses of data and derived parameters, settings, distances to source regions, as well as seasonality of wind. Several studies have examined time-series of TSP and PM10 on the Grand Canary Islands (e.g., Gelado-Caballero et al., 2012; Viana et al., 2002) that lie occasionally in the paths of dense dust plumes from the Sahara and the Sahel. The 
daily TSP deposition found at most sites in our study was much greater than those found by GeladoCaballero et al. (2012) at a high-elevation, remote site and at an urban site, both on Gran Canaria

(geometric mean $<50 \mu \mathrm{g} \mathrm{m}^{-3}$ day $^{-1}$ between 2002 and 2009; mostly $<25 \mu \mathrm{g} \mathrm{m}^{-3}$ day $^{-1}$ at the remote site). Over the course of our study, by contrast, geometric means of daily TSP values (in $\mu \mathrm{g} \mathrm{m}^{-3}$ day $^{-1}$ ) were 119 at CNP, 74 at MVNP, 50 at TEL, 26 at NIW, and 108 at SGS. The proportion of PM10 to TSP was given as 0.63 (Gelado-Caballero et al., 2012) and about 0.70 (Viana et al., 2002). We found lower proportions of PM10 to TSP (0.07 at CNP, 0.11 at MVNP, 0.19 at TEL, and 0.24 at NIW), probably reflecting proximity of these sites to source regions in the western interior U.S. along with particle-size sorting with increasing transport distance.

\subsection{Uncertainties}

A number of uncertainties in our characterization of airborne concentrations of particulate matter are important to acknowledge. Firstly, minor amounts of material may have been lost from the tops of filters during collection and handling despite care taken to eliminate this possibility. We lack information to quantify potential losses, but any such losses would have resulted in underestimation of concentrations. Under-measurement of TSP concentrations would also result from decreased efficiency with increasing particle size, especially greater than $30 \mu \mathrm{m}$ (Neff et al., 2013). Secondly and unavoidably, filters were rarely collected at exactly the same times across the network. Continuous sampling of dust particles in remote sites is challenging, and thus data from such studies have limitations. The alternative approach of periodic, coordinated sampling employed by networks such as IMPROVE avoids the problems of asynchronous sampling but at the expense of information on continuous particle deposition. Despite these issues in sampling, several factors point to robustness of our results: (1) Consistent seasonal variation in TSP concentrations, including commonly high TSP 
concentrations during late winter-spring when Pacific frontal systems dominate storm patterns, (2) close and consistent correspondence among TSP, fine-, and coarse-particle fractions (Fig. 7), and (3) consistencies among observations of dust events, wind patterns, and measurements of TSP concentrations within a sampling interval across the region as discussed above and by Neff et al. (2013). 4.4. Other sources of particulate matter in the western interior U.S.

It is well documented that some dust deposited in the western U.S. has far distant sources, involving transport from Asia especially (e.g., VanCuren and Cahill, 2002; VanCuren, 2003; Zhao et al., 2008; Uno et al., 2011) and also eastern North Africa (Creamean et al., 2013). Nearly all dust advected to the West Coast of North America must be transoceanic (see Husar et al., 2001) expectedly as $\mathrm{PM}_{10}$ (but see Lawrence and Neff, 2009; Menéndez et al., 2014; van der Does et al., 2015). As an exception, periodic dust fall from inland desert sources reaches the coast carried by seasonal Santa Ana winds (Takata et al., 1976; Guazzotti et al., 2001). In the western interior U.S., we found high concentrations of regional dust as TSP and mostly as $\mathrm{PM}_{>10}$. These concentrations must overwhelm (on a mass basis) those of far-traveled Asian and North African dusts that are measured and modeled as $\mathrm{PM}_{2.5}$ and (or) $\mathrm{PM}_{10}$ (e.g., Fairlie et al., 2007; Park et al., 2007). To strengthen this point, we have also documented herein that some coarse-fraction $\left(\mathrm{PM}_{2.5-10}\right)$ and a component of the fine-fraction $\left(\mathrm{PM}_{2.5}\right)$ dust at our TSP collecting sites are derived from regional dust sources, particularly during periods of strong wind (see also Alastuey et al., 2005; Hand et al., 2012, 2015; Neff at al., 2013; Reynolds et al., 2014; Baddock et al., 2014; Axson et al., 2016). These results underscore the importance of distinguishing between transoceanic dust and regional dryland dust with respect to their effects on air quality and ecosystems. We conclude that mineral-PM pollution in our study area is dominantly controlled by regional dust emission and infer that such a condition applies elsewhere in the western interior U.S. This conclusion is indirectly strengthened by other studies, using different methods and covering different temporal and 
spatial scales, that document aspects of regional dust emission and (or) deposition in western North America (e.g., Kavouras et al., 2007; Park et al., 2007; Murphy et al., 2008; Neff et al., 2008; Shafer and Steenburgh, 2008; Utah Division of Air Quality, 2008; 2009; Rivera-Rivera et al., 2010; Hahnenberger and Nicoll, 2012, 2014; Hand et al., 2011, 2012, 2016; Lee et al., 2012; Miller et al., 2012; Steenburgh et al. 2012; Li et al., 2013; Brahney at al., 2013; Lawrence et al., 2013; Lei and Wang, 2014; Reynolds et al., 2014; Huang et al., 2015; Axson et al., 2016; Routson et al., 2016). Our results are unique with respect to direct measurement of TSP concentrations and comparison of these to $\mathrm{PM}_{2.5}$ and $\mathrm{PM}_{10}$ concentrations over several years and covering a regional spatial scale across a variety of ecosystems and human land uses.

The broad distinction in dust source - regional vis-à-vis transoceanic - is relevant to public policy. Yu et al. (2012), estimating that the mass of transoceanic aerosols is comparable to mass of domestically emitted aerosols, argued that curbing North American emissions of PM and other aerosols would not meaningfully mitigate aerosol effects in North America (see also Park et al., 2006). This suggestion may be relevant to aerosols on the West Coast. However, this advice does not appear to be appropriate for the western interior U.S. inasmuch as we show that nearly all TSP, including much $\mathrm{PM}_{10}$, in this region is likely from dust sources within North America. Here, we emphasize the importance of measuring and understanding regional TSP concentrations with respect to air quality and other effects. In this light, an expanded study of TSP concentrations, along with fine- and coarse-size fractions, over a larger area than the one in this study would be highly valuable.

\section{Summary and conclusions}

Total suspended particulates were deposited in high concentrations along a 500-km sampling transect in the western interior United States during 2011-2012. The transect ran from the southwest in high desert to the northeast across the Rocky Mountains to a site on the Great Plains. High 
concentrations of large (greater than $10 \mu \mathrm{m}$ in diameter; $\mathrm{PM}_{>_{10}}$ ) mineral particles from regional dust emissions drove these high concentrations of TSP, especially during late winter through spring when strong winds in Pacific frontal storms commonly track across western deserts to produce regional dust storms and events. Sporadically high TSP and $\mathrm{PM}_{>10}$ concentrations during summer months were likely related to storms generated by the North American Monsoon. Derived from approximately two-week collections of continuous sampling, daily TSP concentrations greatly exceeded concentrations of $\mathrm{PM}_{10}$ and $\mathrm{PM}_{2.5}$ measured over the same time periods.

As a regional measure, concentrations of $\mathrm{PM}_{>10}$ and TSP were correlated to coarse $\left(\mathrm{PM}_{2.5-10}\right)$ and to fine $\left(\mathrm{PM}_{2.5}\right)$-particle concentrations. These results reveal the importance of regional dust within the interior West vis-à-vis intercontinental dust transport by confirming that large proportions of the coarse and fine fractions were generated during regional dust events and not in Asia. These distinctions are important because dust deposition in the western interior U.S. bears on (1) issues of public health (Crooks et al., 2015) and visibility in protected viewsheds; (2) the rate and timing of snow-cover melting as a water-resource management issue; (3) dry landscape conditions and stressors as land-management issues; (4) the transfer of particulate matter and associated nutrients across ecosystems for understanding biogeochemical cycles of soil formation, weathering, and limnologic change; and (5) potential roles in promoting or suppressing precipitation.

Our observations raise concern that much air pollution caused by mineral particulates in the nonurban western interior U.S. goes undetected by $\mathrm{PM}_{10}$ and $\mathrm{PM}_{2.5}$ monitoring, and we thus suggest that measurement of $\mathrm{PM}_{2.5}$ and $\mathrm{PM}_{10}$ alone provides inadequate monitors for air-quality in similar remote settings. These observations should compel renewed efforts to measure all mineral-dust aerosols within the regional spatial scale to evaluate air quality. Worthy of future attention are determinations of certain elements in TSP known to have specific effects on human and ecosystem health. Examples include 
potentially toxic metals, nutrients such as phosphorus, and iron in iron oxide minerals, which influence radiative properties and nucleation of ice in clouds.

\section{Acknowledgments}

We thank Corey Lawrence for improving an earlier version of the manuscript and Paco VanSistene for preparing Figure 1. We gratefully acknowledge the assistance of the U.S. National Park Service (NPS) including Joe Carlson, Kevin Moore, and Lofton Wiley at Canyonlands National Park, George San Miguel and Paul Bohmann at Mesa Verde National Park, and Mark Miller for access and permissions. We are further grateful for the support by Mark Lindquist at the SGS site, the San Miguel County Department of Public Health at the TEL site, and the University of Colorado Mountain Research Station at the NIW site. Rich Sutton and Rian Bogle (both USGS) were responsible for creating the record of dust storms from satellite retrievals. Frank Urban (USGS) provided remote digital camera images of atmospheric dust at the CNP and MVNP sites and at other locations that enabled direct observations of regionally widespread dust. Chris Landry (Colorado Snow and Avalanche Center) kindly provided samples of dust-on-snow. Access to IMPROVE data at http://vista.cira.colostate.edu/improve/ is gratefully acknowledged. This research was supported by the Climate and Land-Use Change and the Status and Trends Programs of the U.S. Geological Survey. Any use of trade, product, or firm names in this article is for descriptive purposes only and does not imply endorsement by the U.S. Government.

\section{References}

Alastuey, A., Querol, X., Castillo, S., Escudero, M., Avila, A., Cuevas, E., Torres, C., Romero, P-M., Exposito, F., García. O., Diaz, J.P., Van Dingenen, R., Putaud, J.P., 2005, Characterisation of TSP and PM2.5 at Izaña and Sta. Cruz de Tenerife (Canary Islands, Spain) during a Saharan Dust Episode (July 2002). Atmospheric Environment 39, 4715-4728. doi:10.1016/j.atmosenv.2005.04.018.

Axson, J.L., Shen, H., Bondy, A.L., Landry, C., Welz, J., Creamean, J.M., Ault, A.P., 2016, Transported mineral dust deposition case study at a hydrologically sensitive mountain site: Size and composition shifts in ambient aerosol and snowpack. Aerosol and Air Quality Research 16, 555-567; doi:

10.4209/aaqr.2015.05.0346. 
Baddock, M.C., Strong, C.L., Leys, J.F., Heidenreich, S.K., Tews, E.K., McTainsh, G.H., 2014, A visibility and total suspended dust relationship. Atmospheric Environment 89, 329-336.

doi:10.1016/j.atmosenv.2014.02.038.

Baldasano, J.M., Valera, E., Jiménez, P., 2003: Air quality data from large cities. The Science of the Total Environment 307, 141-165. doi:10.1016/S0048-9697(02)00537-5. http://dx.doi.org/10.1016/S0048-9697(02)00537-5.

Ballantyne, A.P., Brahney, J., Fernandez, D., Lawrence, C.L., Saros, J., Neff, J.C., 2011, Biogeochemical response of alpine lakes to a recent increase in dust deposition in the Southwestern, US. Biogeosciences 8, 2689-2706, 2011. www.biogeosciences.net/8/2689/2011/, doi:10.5194/bg-8-26892011.

Belnap, J., Reynolds, R.L., Reheis, M.C., Phillips, S.L., Urban, F.E., and Goldstein, H.L., 2009, Sediment losses and gains across a gradient of livestock grazing and plant invasion in a cool, semi-arid grassland: Aeolian Research 1, 27-43.

Brahney, J., Neff, J.C., Ballantyne, A.P., 2013, Increasing Ca2+ deposition in the western U.S.: The role of mineral aerosols. Aeolian Research 10, 77-87. http://dx.doi.org/10.1016/j.aeolia.2013.04.003.

Brahney, J., Ballantyne, A.P., Kociolek, P., Spaulding S., Otu M., Porwoll, T., Neff, J.C., 2014, Dust mediated transfer of phosphorus to alpine lake ecosystems of the Wind River Range, Wyoming, USA. Biogeochemistry 120 (1-3), 259-278. doi:10.1007/s10533-014-9994-x.

Brazel, A.J., Nickling, W.J., 1987, The relationship of weather types to dust storm generation in Arizona (1965 - 1980). International Journal of Climatology 6, 255 - 275.

Carleton, A.M., 1987, Summer circulation climate of the American Southwest, 1945-1984. Annals of the Association of American Geographers 77, 619-634.

Chan, Y.C., McTainsh, G.H., Leys, J.F., McGowan, H.A., Tews, E.K., 2005, Influence of the 23

October 2002 dust storm on the air quality of four Australian cities. Water Air Soil Pollution 164, 329348 .

Changery, M.J., 1983, A dust climatology of the western United States. Prepared for the Division of Health, Siting, and Waste Management Office of the National Research Council. NOAA, National Climatic Data Center.

Claiborne, C.S., Finn, D., Larson, T.V., Koenig, J.Q., 2000, Windblown dust contributes to high PM2.5 concentrations. Journal of the Air and Waste Management Association 50 (8), 1440-1445.

Clow, G.D., Reynolds, R.L., Urban, F.E., Bogle, R.C., Vogel, J.M., 2009, Influence of complex terrain on wind fields in the Mojave Desert, southwestern U.S.: EOS, Transactions of the American Geophysical Union 90(52), Fall Meeting Supplement. Abstract EP21A-0561. 
Creamean, J.M., Spackman, J.R., Davis, S.M, White, A.B., 2014, Climatology of long-range transported Asian dust along the West Coast of the United States. Journal of Geophysical Research 119(21), 12,17112,185. doi: 10.1002/2014JD021694.

Crooks, J.L., Cascio, W., Oercy, M., Reyes, J., Neas, L., Hilborn, E., 2015, Dust storms in the United States are associated with increased cardiovascular mortality. Circulation 132 (Suppl 3), A16822.

de Longueville F., Ozer P., Doumbia S., Henry S., 2013, Desert dust impacts on human health: an alarming worldwide reality and a need for studies in West Africa. Int. J. Biometeorol. 57, 1-19.

Draxler, R.R., Hess, G.D., 2004, Description of the Hysplit_4 modeling system. NOAA Technical Memorandum ERL ARL-224; Air Resources Laboratory, Silver Spring, Maryland, 19 p. http://warn.arl.noaa.gov/documents/reports/arl-224.pdf.

Fairlie, T.D., Jacob, D.J., Park, R.J., 2007, The impact of transpacific transport of mineral dust in the United States. Atmospheric Environment 41 (2007) 1251-1266.

Field, J.P., Belnap, J., Breshears, D.D., Neff, J.C., Okin, G.S., Whicker, J.J., Painter, T.H., Ravi, S., Reheis, M.C., Reynolds, R.L., 2009, The ecology of dust: Frontiers in Ecology and the Environment 8 (8), 423-430. doi:10.1890/090050.

Flagg, C., Neff, J.C., Belnap, J., Reynolds, R.L., 2014, Spatial and temporal patterns of dust emissions (2004-2012) in semi-arid landscapes, southeastern Utah, USA. Aeolian Research 15, 31-43. http://dx.doi.org/10.1016/j.aeolia.2013.10.002.

Fryrear, D.W., Saleh, A., 1993, Field wind erosion: vertical distribution. Soil Science. 155, 294-300.

Fryrear, D.W., Stout, J.E., Hagen, L.J., Vories, E.D., 1991, Wind erosion: field measurement and analysis. Trans. Am. Soc. Agric. Eng. 34, 155-160.

Gelado-Caballero, M.D., López-García, P., Prieto, S., Patey, M.D., Collado, C., Hérnández-Brito, J.J., 2012, Long-term aerosol measurements in Gran Canaria, Canary Islands: particle concentration, sources and elemental composition. Journal of Geophysical Research 117,

D03304.http://dx.doi.org/10.1029/2011JD016646.

Ghio, A.J., Kummarapurupu, S.T., Tong, H., Soukup, J.M., Dailey, L.A., Boykin, E., Gilmour, M.I., Ingram, P., Roggli, V.L., Goldstein, H.L., Reynolds, R.L., 2014, Biologic effects of desert dust in respiratory epithelial cells and a murine model. Inhalation Toxicology, 26(5): 299-309. DOI: 10.3109/08958378.2014.888109.

Ginoux, P., Prospero, J.M., Gill, T.E., Hsu, N.C., Zhao, M., 2012, Global-scale attribution of anthropogenic and natural dust sources and their emission rates based on MODIS deep blue aerosol products. Reviews of Geophysics 50, RG3005.

Goudie, A.S., Middleton, N.J., 2006, Desert dust in the global system: Berlin, Springer, 287 p. 
Guazzotti, S.A.,Whiteaker, J.R., Suess, D., Coffee, K.R., Prather, K.A., 2001, Real-time measurements of the chemical composition of size-resolved particles during a Santa Ana wind episode, California USA. Atmospheric Environment 35 (19), 3229-3240.

Hahnenberger, M., Nicoll, K., 2012, Meteorological characteristics of dust transport events in the Eastern Great Basin of Utah, USA. Atmospheric Environment 60, 601-612 doi10.1016/j.atmosenv.2012.06.029, 601-612.

Hahnenberger, M., Nicoll, K., 2014, Geomorphic and land cover identification of dust sources in the eastern Great Basin of Utah, U.S.A. Geomorphology 204, 657-672.

Hand, J.L., et al., 2011, IMPROVE (Interagency Monitoring of Protected Visual Environments): Spatial and seasonal patterns and temporal variability of haze and its constituents in the United States, Report V, Cooperative Institute for Research in the Atmosphere, Fort Collins, Colo. http://vista.cira.colostate.edu/improve/Publications/Reports/2011/2011.htm.

Hand, J.L., Schichtel, B.A., Pitchford, M., Malm, W.C., Frank, N.H., 2012, Seasonal composition of remote and urban fine particulate matter in the United States, Journal of Geophysical Research 117, D05209, doi:10.1029/2011JD017122.

Hand, J.L., White, W.H., Gebhart, K.A., Hyslop, N.P., Gill, T.E., Schichtel, B.A., 2016, Earlier onset of the spring fine dust season in the southwestern United States. Geophysical Research Letters, 43, doi:10.1002/2016GL068519.

Huang, M., Tong, D., Lee, P., Tang, Y., Stajner, I., Pierce, R.B., McQueen, J., Wang, J., 2015, Toward enhanced capability for detecting and predicting dust events in the western United States: the Arizona case study. Atmos. Chem. Phys. 15, 12595-12610, 2015. doi:10.5194/acp-15-12595-2015.

Husar, R.B. et al., 2001, Asian dust events of April 1998. Journal of Geophysical Research 106 (D16), 18,317-18,330. 2000JD900788. 0148-0227/01/2000JD900788.

Jeglum, M.E., Steenburgh, W.J., Lee, T.P., Bosart, L.F., 2010, Multi-Reanalysis Climatology of Intermountain Cyclones. Monthly Weather Review 138 (11), 4035-4053.

Jewell, P.W., Nicoll, K., 2011, Wind regimes and aeolian transport in the Great Basin, U.S.A. Geomorphology 129, 1-13, doi:10.1016/j.geomorph.2011.01.005.

Jugder, D., Shinoda, M., Kimura, R., Batbold, A., Amarjargal, D., 2014, Quantitative analysis on windblown dust concentrations of PM10 (PM2.5) during dust events in Mongolia. Aeolian Research 14, 3-13. doi:org/10.1016/j.aeolia.2014.04.005.

Kavouras, I.G., Etyemezian, V., Xu, J., DuBois, D.W., Green, M., Pitchford, M., 2007, Assessment of the local windblown component of dust in the western United States. Journal of Geophysical Research 112, D08211, doi:10.1029/2006JD007832. 
Knight, A.W., McTainsh, G.H., Simpson, R.W., 1995, Sediment loads in an Australian dust storm: implications for present and past dust processes. Catena 24, 195-213.

Lawrence, C.R., Neff, J.C., 2009, The contemporary physical and chemical flux of aeolian dust: A synthesis of direct measurements of dust deposition. Chemical Geology, 267 (1-2), 46-63. doi:10.1016/j.chemgeo.2009.02.005.

Lawrence, C.R., Neff, J.C., Painter, T.H., Landry, C.C., 2010, Contemporary geochemical composition and flux of aeolian dust to the San Juan Mountains, Colorado, United States. Journal of Geophysical Research 115, G03007, doi:10.1029/2009JG001077.

Lawrence, C.R., Reynolds, R.L., Ketterer, M., Neff, J.C., 2013, Aeolian controls on soil geochemistry and weathering fluxes in high-elevation ecosystems of the Rocky Mountains, USA: Geochimica et Cosmochimica Acta 107, 27-46.

Lee, J.A., Baddock, M.C., Mbuh, M.J., Gill, T.E., 2012, Geomorphic and land cover characteristics of aeolian dust sources in west Texas and eastern New Mexico, USA. Aeolian Research 3 (4):459- 466. doi:10.1016/j.aeolia.2011.08.001.

Lee, J.A., Tchakerian, V.P., 2005, Magnitude and Frequency of Blowing Dust on the Southern High Plains of the United States, 1947-1989. Annals of the Association of American Geographers; 85 (4), 684-693. DOI: 10.1111/j.1467-8306.1995.tb01820.

Lei H., Wang J.X.L., 2014, Characteristics of dust storm events over the western United States. Atmos Chem. Phys. Disc. 13:14195-14220.

Leys J.F., Heidenreicj S.K., Strong C.L., McTainsh G.H., Quigley S., 2011, PM10 concentrations and mass transport during "Red Dawn”-Sydney 23 September 2009. Aeolian Research 3, 327-342.

Li, R., Wiedinmyer, C., Hannigan, M.P., 2013, Contrast and correlations between coarse and fine particulate matter in the United States. Science of the Total Environment 456-457, 346-358.

Mahowald, N., Albanni, S., Kok, J.F., Engelstaeder, S., Scanza, R., Ward, D.S., Flanner, M.G., 2013, The size distribution of desert dust aerosols and its impact on the Earth system. Aeolian Research 15, 53-71. doi.org/10.1016/j.aeolia.2013.09.002.

Malm, W.C., Sisler, J.F., Huffman, D., Eldred, R.A., and Cahill, T.A., 1994, Spatial and seasonal trends in particle concentration and optical extinction in the United States, Journal of Geophysical Research 99, $1347-1370$.

McTainsh, G.H., Chan, Y., McGowan, H., Leys, J.F., Tews, K., 2005, The 23 October 2002 dust storm in eastern Australia: characteristics and meteorological conditions. Atmospheric Environment 39, 12271236.

McTainsh, G.H., Nickling, W.G., Lynch, A.W., 1997, dust deposition and particle size in Mali, West Africa. Catena 29, 307-322. 
Menéndez, I., Pérez-Chacón, E., Mangas, J., Tauler, E., Englebrecht, J.P., Derbyshire, E., Cana, L., Alonso, I., 2014, Dust deposits on La Graciosa Island (Canary Islands, Spain): Texture, mineralogy and a case study of recent dust plume transport. Catena 117, 133-144.

Midddleton, N.J., Betzer, P.R., Bull, P.A., 2001, Long-range transport of 'giant' aeolian quartz grains: Linkage with discrete sedimentary sources and implications for protective particle transfer. Marine Geology 177, 411-417.

Miller, M.E., Bowker, M.A., Reynolds, R.L., Goldstein, H.L., 2012, Post-fire land treatments and wind erosion - Lessons from the Milford Flat Fire, UT, USA. Aeolian Research 7, 29-44. doi:10.1016/j.aeolia.2012.04.001.

Munson, S.M., Lauenroth, W.K., 2009, Plant population and community responses to removal of dominant species in the shortgrass steppe. Journal of Vegetation Science 20, 224-232.

Munson, S.M., Belnap, J., Okin, G.S., 2011, Responses of wind erosion to climate induced vegetation change on the Colorado Plateau. Proceedings of the National Academy of Science 108, 3854-3859.

Murphy, D.M., Capps, S.L., Daniel, J.S., Frost, G.J., White, W.H., 2008, Weekly patterns of aerosol in the United States. Atmospheric Chemistry and Physics 8, 2729-2739.

Nakata, J.K., Wilshire, H.G., Barnes, G.G., 1976, Origin of Mojave Desert dust plumes photographed from space. Geology 4 (11), 644-648.

Neff, J.C., Ballantyne, A.P., Famer, G.L., Mahowald, N.M., Conroy, J.L., Landry, C.C., Overpeck, J.T., Painter, T.H., Lawrence, C.R., Reynolds, R.L., 2008, Increasing eolian dust deposition in the western United States linked to human activity. Nature - Geosciences 1, 189-195; doi:10.1038/ngeo133.

Neff, J.C., Reynolds, R.L., Munson, S. Fernandez, D., Belnap, J., 2013, The role of dust storms in atmospheric particle concentrations at two sites in the western U.S. Journal of Geophysical Research 118, 11201-11212. doi:10.1002/jgrd.50855.

Neff, J., Reynolds, R.L., Belnap, J., Lamothe, P., 2005, Multi-decadal impacts of grazing on soil physical and biogeochemical properties in Southeast Utah. Ecological Applications 15 (1), 87-95.

Orgill, M.M., Sehmel, G.A., 1977, Frequency and diurnal variation of dust storms in the contiguous U.S.A. Atmospheric Environment 10, 813-825.

Ozer, P., Laghdaf, M.B.O.M., Lemine, S.O.M., Gassani, J., 2006, Estimation of air quality degradation due to Saharan dust at Nouakchott, Mauritania, from horizontal visibility data. Water, Air, and Soil Pollution 178, 79-87. doi:10.1007/s11270-006-9152-8.

Painter, T.H., Deems, J.S., Belnap J., Hamlet, A.F., Landry, C.C., Udall, B., 2010, Response of Colorado River runoff to dust radiative forcing in snow. Proceedings of the National Academy of Sciences 107 (40), 17125-17130; doi: 10.1073/pnas.0913139107. 
Painter, T.H., Skiles, S.M., Deems, J.M., Bryant, A.C., Landry, C.C., 2012, Dust radiative forcing in snow of the Upper Colorado River Basin: 1. A 6 year record of energy balance, radiation, and dust concentrations. Water Resources Research 48, W07521, doi:10.1029/2012WR011985.

Park, R.J., Jacob, D.J., Kumar, N., Yantosca, R.M., 2006, Regional visibility statistics in the United States: Natural and transboundary pollution influences, and implications for the Regional Haze Rule. Atmospheric Environment 40, 5405-5423.

Park, S.H., Gong, S.L., Zhao, T.L., Vet, R.J., Bouchet, V.S., Gong, W., Makar, P.A., Moran, M.D., Stroud, C., Zhang, J., 2007, Simulation of entrainment and transport of dust particles within North America in April 2001 ('"Red Dust Episode')). Journal of Geophysical Research, 112, D20209, doi:10.1029/2007JD008443.

Prospero, J.M., 1996, Saharan dust transport over the North Atlantic Ocean and Mediterranean: An overview. In Guerzoni, S., Chester, R., (Eds.), The Impact of Desert Dust Across the Mediterranean. Kluwer Academic Publishers, Netherlands, pp. 133-151.

Pye, K. 1987, Aeolian dust and dust deposits. London, Academic Press, 334 p.

R Development Core Team, 2015, R: A language and environment for statistical computing. R Foundation for Statistical Computing, Vienna, Austria. Online http://www.R-project.org. Accessed 1 March 2015.

Reheis, M.C., Urban, F.E., 2011, Regional and climatic controls on seasonal dust deposition in the southwestern U.S. Aeolian Research 3, 3-21.

Reynolds, R.L., 2010, Cover picture: Dust storm from a prairie-dog colony in southern Boulder County, Colorado, in January 2009. Frontiers in Ecology and the Environment 8 (8).

Reynolds, R.L., Goldstein, H.L., Moskowitz, B.M., Bryant, A.C., Skiles, S.M., Kokaly, R.F., Flagg, C.B., Yauk, K., Berquó, T., Breit, G., Ketterer, M., Fernandez. D., Miller, M.E., Painter, T.H., 2014, Composition of dust deposited to snow cover in the Wasatch Range (Utah, USA): Controls on radiative properties of snow cover and comparison to some dust-source sediments. Aeolian Research 15, 73-90. doi.org/10.1016/j.aeolia.2013.08.001.

Reynolds, R.L., Mordecai, J., Rosenbaum, J., Ketterer, M.E., Walsh, M.K., Moser, K., 2010, Compositional changes in sediments of subalpine lakes, Uinta Mountains, Utah: Evidence for the effects of human activity on atmospheric dust inputs. Journal of Paleolimnology 44 (1) ISSN 0921-2728, doi:10.1007/s10933-009-9394-8.

Rivera Rivera, N.I., Gill, T.E., Bleiweiss, M.P., Hand, J.L., 2010, Source characteristics of hazardous Chihuahuan Desert dust outbreaks. Atmospheric Environment 44 (20), 2457-2468. 
Routson, C.C., Overpeck, J.T., Woodhouse, C.A., Kenney, W.F., 2016, Three millennia of southwestern North American dustiness and future implications. PLoS ONE 11(2):

doi:10.1371/journal.pone.0149573.

Shafer, J.C., Steenburgh, W.J., 2008, Climatology of strong intermountain cold fronts. Monthly Weather Review 136, 784-807.

Shao, Y.P., 1991, A model for mineral dust emission. Journal of Geophysical Research 106, 2023920254.

Shao, Y., Leys, J.F., McTainsh, G.H., Tews, K., 2007, Numerical simulation of the October 2002 dust event in Australia. Journal of Geophysical Research. 112, D08207. doi:10.1029/2006JD007767.

Shao, Y.P., Wyrwoll, K-H., Chappell, A. Huang, J., Lie, Z., McTainsh, G.H., Mikami, M., Tanaka, T.Y., Wang, X., Yooi, S., 2011, Dust cycle: An emerging core theme in Earth system science. Aeolian Research 2 (4) 181-204.

Skiles, S.M., Painter, T.H., Deems, J.M., Bryant, A.C., Landry, C.C., 2012, Dust radiative forcing in snow of the Upper Colorado River Basin: 2. Interannual variability in radiative forcing and snowmelt rates. Water Resources Research 48 (7), W07522, doi:10.1029/2012WR011986.

Skiles, S.M., Painter, T.H., Belnap, J., Holland, L., Reynolds, R.L., Goldstein, H.L., Lin, J., 2015, Regional variability in dust-on-snow processes and impacts: A multi-year study in the Colorado River Basin. Hydrologic Processes 29 (26), 5397-5413. doi:10.1002/hyp.10569.

Steenburgh, W.J., Massey, J.D., Painter, T.H., 2012, Episodic dust events of Utah's Wasatch Front and adjoining region. Journal of Applied Meteorology and Climatology 51 (9), 1654-1669. doi: http://dx.doi.org/10.1175/JAMC-D-12-07.1.

Stout, J.E., 2001, Dust and environment in the Southern High Plains of North America. J. Arid Environ. 47, 425-441.

Uno, I., Eguchi, K., Sugimoto, N., Shimizu, A., Takemura, T., 2011, Large Asian dust layers continuously reached North America in April 2010. Atmospheric Chemistry and Physics 11, 7333-7341.

Urban, F.E., Reynolds, R.L., Fulton, R., 2009, The dynamic interaction of climate, vegetation, and dust emission, Mojave Desert, USA. In Fernandez-Bernal, A., De La Rosa, M.A. (eds.) Arid Environments and Wind Erosion. NOVA Science Publishers, Inc. ISBN 978-1-60692-411-2. 243-267.

USDA National Agricultural Statistics Service (NASS), 2015, Online: http://www.nass.usda.gov. Accessed 20 February 2015.

Utah Division of Air Quality, 2008, Utah Division of Air Quality PM10 \& PM2.5 exceptional high wind event Cottonwood, Hawthorne, Lindon, North Salt Lake, and North Provo monitoring stations, event date April 19, 2008. Utah Division of Air Quality, Salt Lake City, 96 p. 
Utah Division of Air Quality, 2009, Utah Division of Air Quality PM10 exceptional high wind event Lindon monitoring station, event date March 4, 2009. Utah Division of Air Quality, Salt Lake City, 55 p.

van der Does, M., Korte, L., Munday, C., Brummer, G.A., Stuut, J., 2015, Lateral and seasonal trends of Saharan dust deposition along a transect over the Atlantic Ocean. American Geophysical Union Fall Meeting Abstracts A33L-0356.

VanCuren, R.A., 2003, Asian aerosols in North America: Extracting the chemical composition and mass concentration of the Asian continental aerosol plume from long-term aerosol records in the western United States. Journal of Geophysical Research 108 (D20), 4623. doi:10.1029/2003JD003459.

VanCuren, R.A., Cahill, T.A., 2002, Asian aerosols in North America: Frequency and concentration of fine dust. Journal of Geophysical Research 107 (D24), AAC 19-1-AAC 19-16.

doi:10.1029/2002JD002204.

Viana, M.M., Querol, X., Alastuey, A., Cuevas, E., Rodríguez, S., 2002, Influence of African dust on the levels of atmospheric particulates in the Canary Islands air quality network. Atmospheric Environment 36, 5861-5875.

Yu, H., Remer, L.A., Chin, M., Bian, H., Tan, Q., Yuan, T., Zhang, Y., 2012, Aerosols from overseas rival domestic emissions over North America. Science 337, 566-569.

Wells, K.C., Witek, M., Flatau, P., Kredenweis, S.M., Westphal, D.L., 2007, An analysis of seasonal surface dust aerosol concentrations in the western US (2001-2004): Observations and model predictions. Atmospheric Environment 41 (2007) 6585-6597.

Xiao, H.-Y., Liu, C.-Q., 2004, Chemical characteristics of water-soluble components in TSP over Guiyang, SW China, 2003. Atmospheric Environment 38, 6297-6306.

doi:10.1016/j.atmosenv.2004.08.033. http://linkinghub.elsevier.com/retrieve/pii/S1352231004007770.

Zhao, T.L., Gong, S.L., Zhang, X.Y., Jaffe, D.A., 2008, Asian dust storm influence on North American ambient PM levels: Observational evidence and controlling factors. Atmospheric Chemistry and Physics 8, 2717-2728. 

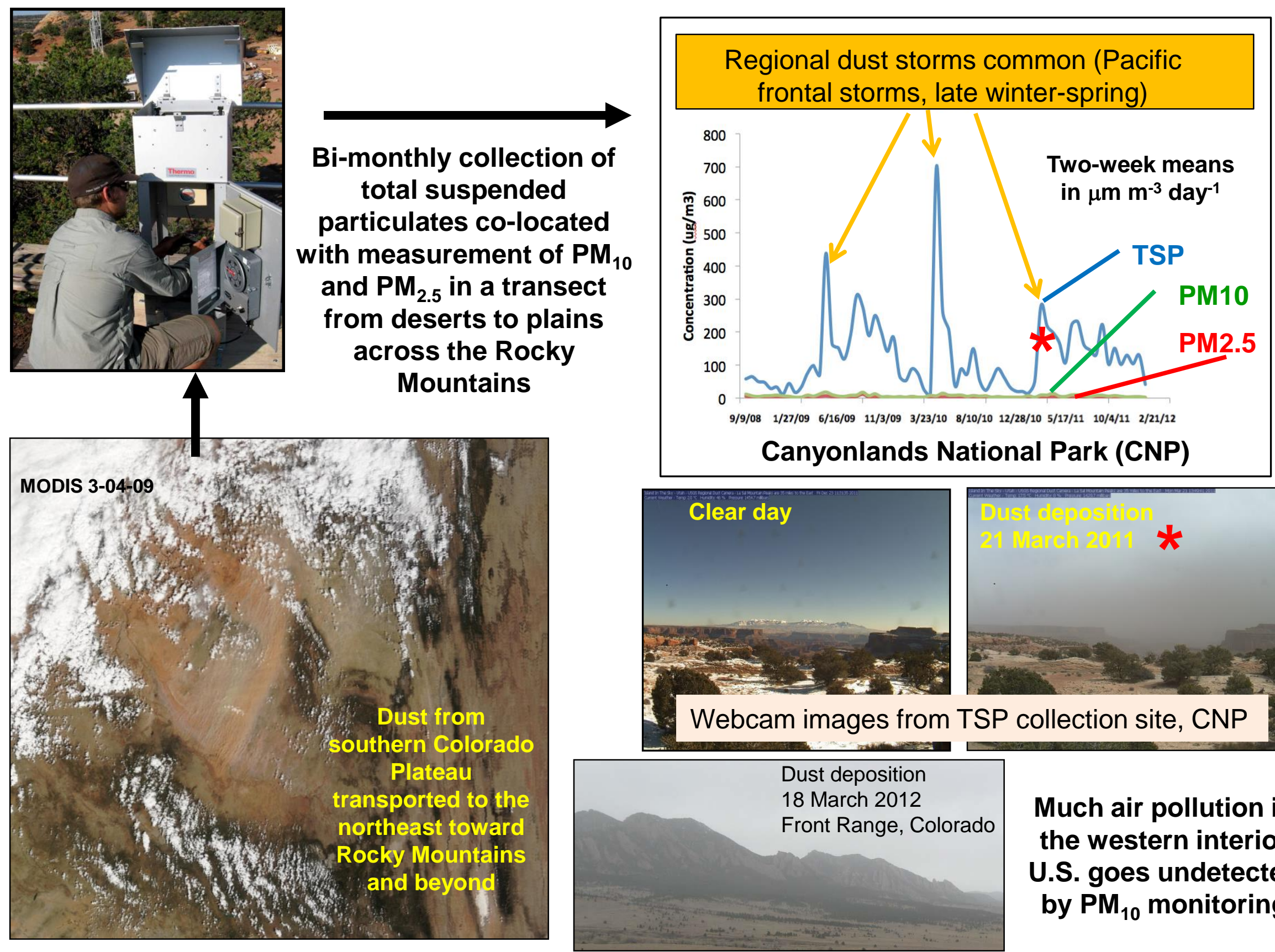

Much air pollution in the western interior U.S. goes undetected by $\mathrm{PM}_{10}$ monitoring 